In: Bauer, M., Gaskell, G. (eds.), Biotechnology. The Making of a global controversy, Cambridge University Press, 21-94

\title{
Promise, Problems and Proxies: 25 Years of European Biotechnology Debate and Regulation
}

\begin{abstract}
By Helge Torgersen*1, Jürgen Hampel*, Marie-Louise v. Bergmann-Winberg, Eleanor Bridgman, John Durant, Edna Einsiedel, Björn Fjaestad, George Gaskell, Petra Grabner1, Petra Hieber, Erling Jelsoe, Jesper Lassen, Athena Marouda-Chatjoulis, Torben Nielsen, Timo Rusanen, Georges Sakellaris, Franz Seifert1, Carla Smink, Tomasz Twardowski, Merci Wambui-Hovmand (*convenors).
\end{abstract}

\section{Introduction: Biotechnology - A Chequered Field}

At the end of the century, disputes about biotechnology and its agricultural products have reached a peak in Europe. Industry has failed to win the hearts of European consumers and, de facto, there is still no real harmonisation of product assessment within the EU. This is noteworthy since after a quarter of a century of rapid scientific and technological development on the one hand, and contentious debates about real or possible implications on the other, biotechnology has 'come of age'. Industry has finally engaged in biotechnology on a broad base, forming large conglomerates that deal with seeds as well as with pharmaceuticals under the heading of 'life science'. Ten, or even five years ago, most spectators expected disputes over biotechnology to be settled imminently; nevertheless, issues are again subject to conflicts to such a degree that the future of some applications of biotechnology in Europe is uncertain. Obviously, traditional ways of introducing this new technology have failed. But can we establish why?

Classically, authors understood the relationship between technology and society to involve the latter adapting to technological developments (see Ogburn, 1957; Ellul, 1964). They saw technology as relatively independent of society, following its own rationality, or even forcing society to adapt to it. According to this view, it is inevitable that society 'culturally lags' behind technology, because technological development is faster than social and cultural adaptation (Ogburn, 1957). Society seeks to catch up, while new technological developments constantly open new gaps.

Indeed, the introduction of a new technology often seemed to follow this schema. For example, communication and information technologies raised debates in the eighties (stimulated by Orwell's famous novel '1984'); but now, after the 'cultural lag' has been narrowed, they constitute welcome elements of everyday life. However, in the case of biotechnology, this classical model of explaining technological innovation obviously falls short. Here, even an apparent calming of the debate in the early Nineties proved to be only temporary and conflicts have reappeared. 
Uncertainty over possible hazards, from early on, nourished struggles over biotechnology. It is a truism that every technological innovation is associated with risks or even hazards remember explosions involving steam engines, or airplane crashes in the pioneer days of aviation. The difference here was that there was uncertainty as to whether there were any hazards at all. Opponents of biotechnology strenuously advanced claims of risks, while supporters denied them with equal assiduity. It is not our objective to determine whether any of these claims have been substantiated, or whether the risks identified are only hypothetical. Rather, in this chapter we attempt to trace opinions about whether there are risks, and if so, of which kind, as well as the political consequences thereof.

At the heart of many controversies about risk lies a difference between public and expert experience of what biotechnology 'really' is. For the general public, this is not a technology like any other, since specific installations and artefacts ${ }^{2}$ are not easily discernible. An atomic power plant served as a symbol for nuclear technology, and computers were typical products of microelectronics. Without these practical applications, the technology would not have existed. In contrast, biotechnology is usually invisible to laymen. Although applied in many fields, its techniques are employed behind closed doors in laboratories indistinguishable from outside. As such, at first glance, its products are not at all specific. Biotechnology consequently remains enigmatic, at the same time as dealing with 'the secret of life'. In contrast, for experts, its character is no different from that of other technologies. Biotechnology laboratories are, for them, definitely recognisable, containing, as they do, specific apparatuses for research and production. To the expert, their products are clearly distinguishable by their properties, and no other technology could have produced them. Moreover, for the skilled, biotechnology did not pose intrinsic problems that could not be understood, and controlling the mechanisms of heredity, in principle, does not present insurmountable problems.

In order to deal with uncertainty, and to make risks in many fields calculable and manageable, engineers and insurers have developed (technical) risk assessments. Although 25 years have elapsed without a single major accident caused by biotechnology, 3 expectations among scientists that they would be able to comprehensively and credibly identify, control, compare and evaluate the technical risks of biotechnology have, nonetheless, failed. One major reason for this is that, due to the subject of biotechnology being 'life' itself, ethical considerations played a significant role from the very beginning. Hence, debates transgressed the discussion of technical aspects, and especially those involving risks that could be technically determined. Indeed, in its status as a contested issue, biotechnology served as a sounding board, or a projection screen, for deep differences in interests and world-views. This resulted in a wide opening of the debate and the forging of links with other issues considered to be at stake.

Such a transgression could also be observed in the case of nuclear energy and, to a much lesser degree, with micro-electronics. Both technologies had acquired the position of strategic technologies long before biotechnology, although the latter was assigned this status soon after its birth (Bauer, 1998). Differences arose in the perceived need to regulate these technologies: with nuclear energy, the demand for regulation by the government was obvious; but all but a few agreed that the regulation of microelectronics was hardly feasible. In 
contrast, the struggle over biotechnology led to an ambiguous result, since different actors failed to agree on the issue of regulation, and different groups sought to delay or to support the use of biotechnological applications. Debates went beyond the question of whether or not a law should be passed, to the issue of the appropriate contents of regulatory policies. The latter became an especially contested topic not only within Europe, but also between the USA - as a promoter of a regulatory approach based on scientific evidence alone - and the European Union (EU), which was opting for a broader basis of argument.

Responding to competing interests, governments adopted different permutations of a twosided policy: on the one hand, they provided regulation as a means of containing risks, on the other hand, they backed research and application in order to stay, or become, economically competitive (Jasanoff, 1995). This strategy seemed appropriate in order to 'make biotechnology happen'.4 Obviously, governments thought that biotechnology was something worth developing and they supported it with alacrity. Yet, they also styled themselves as impartial regulators of what many pervceived to be a risky endeavour. This ambiguity later proved to be one of the sources of public distrust.

Despite this general pattern, the style and background of the debates and their political outcomes differed markedly from country to country, and subjects, actors and fora changed considerably over time. Even among EU5 member states, we encounter an astonishing multitude of reactions to the challenges that biotechnology presented, both in terms of public debate as well as of regulation. Even differences in regulatory style influenced how biotechnology was perceived, and which of the problems raised by different actors were deemed legitimate areas of state involvement. In order to gain an understanding of what may appear, at first glance, an odd and almost impenetrable jungle of rhetoric and facts, policies and interests, opportunities and risks, wishes and fears, attitudes and world views, we have to examine this varied picture and explore its determining factors.

Much has been written about this issue over time.6 As such, the following chapter draws upon a wealth of data, resulting from four years of concerted research, by an international group of scientists coming from various disciplines. This research covers policy initiatives, media coverage and public attitudes towards biotechnology in 13 European countries, as well as in the US and Canada (compiled in Durant et al., 1998). 7

\section{Concepts and Methodology}

In the following, we will trace the entangled history of biotechnology debate and policymaking during the last quarter of a century. We will keep in mind the four general issues that have been outlined in the previous paragraph (table 1): firstly, the transgression of the boundaries of technical risk issues in the debates, which indicate that biotechnology acquired the role of a sounding board for the articulation of deeper concerns; secondly, the challenging of the technocratic paradigm of an autonomous chain of innovation; thirdly, the prevalence of regulatory responses intended to make biotechnology happen in the context of a two-sided policy of regulation and support; and finally, the difficulties for the EU common market presented by the existence of profound differences among the nations of the EU in their 
attitudes towards biotechnology. These themes are, of course, interrelated; for example, the transgression of risk issues in the debates contributed significantly to those delays and detours (even cul-de-sacs), encountered in attempts to implement biotechnology, that served to challenge the innovation chain paradigm. And many governments' dual strategies for encouraging biotechnology were inevitably embedded in national political styles. Different emphases in the various countries on the perceived problems concerning biotechnology made the sounding-board play different tunes, and facilitated or hindered governments to fall back into their perception of the innovation chain.

Table 1: General Issues

\begin{tabular}{|l|}
\hline Sounding board: the transgression of risk issues \\
\hline Challenging the traditional innovation chain paradigm \\
\hline Dual strategy in order to make biotechnology happen \\
\hline National variations across the EU \\
\hline
\end{tabular}

Over time, we not only observe developments in biotechnology per se, but also of the meaning of the word. Therefore, before looking at the history of this technology it is necessary to provide some provisional definitions of terms, since at different times stakeholder groups have used different terminology (see table 1).8 For the sake of simplicity, we will stick to the term 'biotechnology' even if we refer to developments that scientists would consider to fall outside of this categorisation. In general, however, we will focus on applications made possible by research on nucleic acids, which became apparent during the Seventies under the heading of 'genetic engineering'. But since biotechnology, even in this sense, is a very broad field, we have to restrict the scope of this investigation somewhat. We will therefore concentrate on those issues that are commonly covered by national biotechnology regulation. We will particularly emphasise the problems surrounding the release and placing on the market of geneticaly modified organisms (GMOs), since it is such products that have triggered the most intense public debate in recent years, as recorded by the Eurobarometer 46.1 survey (INRA 1997, BEP 1997, Durant et al., 1998).

Debates arose among regulators and those involved in $\mathrm{R} \& \mathrm{D}$, but also among the general public. We are aware that it is not easy to define what this 'public' constitutes: there are many conceptualisations of the 'public' among social scientists, 9 and probably there are different 'layers' of the 'public' as well. Thus, we tend to assume a pragmatic approach, adopting an understanding of the public as an entity that carries 'public perceptions' about biotechnology (see Gaskell et al., 1998, pp.9-10).10

The political problems associated with biotechnology changed over time as the technology matured from a set of methods for basic research to techniques for applications and products in various fields. Consequently, 'biotechnology policy' meant something different in each of these fields. Debates arose within many political arenas, such as Parliaments, political parties, professional societies, but also in newspapers and other media. Actors, such as scientists, politicians, industry representatives, activists from Non-Governmental Organisations (NGOs),11 well-respected intellectuals, etc. demanded different degrees of regulation. 
Since the political reasons for regulation varied among countries, a multitude of ways of regulating biotechnology emerged, including special laws, adaptations of existing regulation, statutory guidelines and self-regulation. Clearly, regulation could take on very different forms, according to the type of actor each intervention was aimed at, and the functions it was intended to fulfill. As with most new technologies, from the very beginning the overall aim of attempts to control aspects of biotechnology was to provide a reliable frame under which it could be pursued safely whilst it was being implemented and promoted. Thus, keeping in mind the varieties of approaches involved, when we speak of regulation we refer to any means of applying rules to an aspect of biotechnology; if this is by law, we call it legal regulation.

Table 2: Definitions

\begin{tabular}{|l|l|}
\hline biotechnology & $\begin{array}{l}\text { recombinant DNA techniques as well as methods for their } \\
\text { practical application in various fields }\end{array}$ \\
\hline $\begin{array}{l}\text { recombinant DNA techniques, } \\
\text { genetic engineering }\end{array}$ & $\begin{array}{l}\text { combination of methods for splitting, sequencing, splicing } \\
\text { and constructing genes }\end{array}$ \\
\hline genetically modified organisms & organisms that carry genes modified by these techniques \\
\hline products of biotechnology & results of production processes applying such methods \\
\hline (general) public & societal entity that carries, public perceptions \\
\hline regulation & means to put an aspect of biotechnology under rules \\
\hline
\end{tabular}

\section{Phases}

In this chapter, we are dealing with the social and political reactions to, and conflicts over, technological, social, and political developments with respect to biotechnology. This task is complicated not only because of the complexity and variability of the technology itself, but also because conflicts, debates, and political reactions occurred in a bewildering array of temporal and spatial contexts. If we compare the history of debates and policy-making across Europe (Durant et al, 1998), we see numerous periods in which public attention and policy initiatives were negligible, alternating with more active periods. Likewise, we see activity in different countries at different points in time.

There are many reasons for this variegated picture. In Europe in this period, a loose economic community was changing its character to become an increasingly integrated system of member states. Yet, in spite of this integration, the political cultures and legal systems in European countries remain very different. Some legal systems are oriented towards Germanic law, while others follow Roman law. Countries with a first-past-the-post electoral system sit alongside countries with proportional representation that lowers the hurdles for the formation of new political parties. Some countries saw the development of Green parties in this period, others did not. As well as the threshold for parliamentary representation differing across Europe, the way in which the political systems reacted to public unease varied considerably. In addition, the responsiveness of governments may have changed over time, since during the 25 years covered each European country experienced at least one change of government. 
Initially, the asynchrony across Europe was most noticeable between the North and the South. Countries in the vanguard of technological development, political debates and regulation from the North and West of Europe had been dealing with the issue since the Seventies. Some of them witnessed widespread debate and others tried out various styles of regulation. These nations set the agenda for other countries, but some of the latter followed only after a delay of up to twenty years. Regarding the form of regulation, almost every country adopted a different position. The variety of approaches and responses in the European countries, and the fact that the EU institutions added another layer of regulation in an attempt to impose some harmonisation, makes generalising extremely difficult. Thus, at first glance, producing a comparative analysis of the political debates and regulation of biotechnology in Europe might seem to be a hopeless enterprise.

However, regardless of all the intra- and inter- national differences, it is possible to identify some common characteristics. If we step back and take a birds' eye view, some similarities and general patterns emerge with the help of comparative media analysis (Durant et al., 1998). Such analyses reveal the existence of common themes, or 'frames', representing the main interpretations of the opportunities and challenges for biotechnology. These frames were characterised by a shared set of problems, reference to similar stages in the development of the technology, and the expression of specific views that predominated among important actors. From our analysis of the main issues in European public debates and policy-making involving biotechnology over the last 25 years, we have discerned four phases, exemplified by distinct and overarching frames (table 3 ). Thus, it seems that after a short period of time, the media emphasis shifted from laboratory science to industrial and economic aspects, subsequently moving onto the question of the EU's harmonisation of regulation, and, finally to the issue of consumer market products.

Table 3: Phases

Phase 1 (from1973): Scientific Research

Phase 2 (from 1978): Competitiveness, Resistance and Regulatory Responses

Phase 3 (from 1990): European Integration

Phase 4 (from 1996): Renewed Opposition: Consumers

The view of biotechnology as a scientific endeavour was the first of several successive frames. Early 1970s coverage was, almost universally, characterised by a conceptualisation of biotechnology as an area of promising scientific research. While the issue of risk was stressed at this stage, it was discussed by scientists themselves, who soon came to the conclusion that the risks were manageable. When, in some countries, public opposition emerged, scientists made attempts to reassure the public.

Later, this prevailing view of biotechnology gave way to a more practically oriented perception. It came to be recognised that biotechnology might gain enormous economic importance in an increasingly competitive world. Hence, it had to be defended against resistance arising out of safety fears. Scientists from other fields had developed counter arguments, and these were taken up by critics. Opponents also asserted links with other 
contested issues, and the moral status of biotechnology - rendering life itself malleable - gave rise to concerns. As a result, it became clear to many governments that self-regulation by scientists could not provide a satisfactory degree of protection against the perceived risks. In an attempt to confine the issues at stake, some governments began to regulate the field on a national basis.

The divergence of views as to the appropriate way of regulating biotechnology eventually led the EU's institutions to take responsibility. It was hoped that this would engender some degree of harmonisation in the common market. This proved to be problematic, since regulatory styles and the history of the debate in the member countries varied so profoundly. Eventually, however, resistance faded and it appeared as if biotechnology had become a wellregulated and accepted technology.

Yet, when consumer products materialised, old conflicts reopened over new issues and the opposition was renewed. As consumers, citizens had a powerful voice, and it became obvious that existing modes of regulation appeared inadequate to many, and that national governments and EU institutions would have to find new solutions. Conflicts reached an unprecedented level even in countries where people had previously been fairly positive towards biotechnology.

The phases of the debate outlined above not only reflect the progression of the technology, as conventional innovation theory would predict, but they also represent changes in the political, social, cultural and economic environment of biotechnology. This is illustrated by certain prevailing frames in the debates and by the character of particular policy initiatives at different stages. These frames were certainly not synchronous everywhere, rather, they overlapped differently for each country and field of application. Indeed, challenges did not occur at the same time in different parts of Europe and problems had not necessarily been solved when the new phase began. The subjects of earlier phases retained relevance in later stages. As such, the phases we stipulate indicate the addition of further layers of complexity rather than fundamental changes in the issues at stake (see table 3 ).

One may observe that the debates expanded and contracted during each period. When biotechnology was seen as a scientific endeavour, debates could mostly be settled by scientists voicing safety reassurances. When biotechnology entered society at large, and commercial interests gained momentum, debates expanded once again. Controversy then began to cover applications and emphasised world views, which prompted regulatory responses that often appeased resistance and led to a contraction of debates. The EU took up the issue at this juncture and attempted to harmonise regulatory frameworks. This became a new subject for debate, and inflamed existing controversies; but when biotechnology was formally endorsed, debate contracted once more. However, the commercial release of GMOs again triggered widespread opposition, and today we are in another phase of widespread debate.

This 'phase' structure, underpinned by concrete events, allows us to develop a framework for analysing the development of biotechnology debates and regulations in Europe. It also permits us to trace the four general issues mentioned above as characterising the four phases. 
In the following we will examine the four phases in turn, elaborating those aspects that are important for understanding this rich and complex field. In the conclusion we will then revisit the general issues and, finally, speculate on what the future might hold.

\section{Phase 1 (1973 - 1978): Scientific Research}

When biotechnology appeared for the first time as a public issue, debate was clearly shaped by existing notions of scientific progress and by demands for scientific accountability. From the very beginning, the issue of risk was emphasised and diffused from the level of scientific discussion into the arena of public debate. The objective was to promote scientific research while minimising technical risks and coping effectively with an emerging public debate. We will see how some European countries, with a strong tradition in biotechnology, major industry interests and/or an alerted public, met the new challenges.

\section{A Call for Scientific Accountability}

Methods of splitting, sequencing and splicing genes were developed in the US. The first recombinant DNA result was presented in 1973, involving the successful in vitro transfer of a gene between different species. With the advent of these new scientific techniques, a wave of concern arose in the scientific community about possible safety hazards. They resulted in a moratorium being convened in order to gain some time for scientists to think about the consequences of further research in these fields. Hence, biotechnology was accompanied, from the moment of its birth, by the attribution of risk. This perception continues to this day.

Details published in a letter, entitled 'Potential Biohazards of Recombinant DNA Molecules', to the magazine Science outlined the scientists' concerns. The authors, Paul Berg and colleagues, called for a cautious approach until the hazards were better understood and an international conference could agree on how those risks should be contained. The scientific community felt that controls were necessary in order for work to be continued safely, and they accepted a voluntary moratorium. After eight months, at the Asilomar Conference, it was agreed that the moratorium could be lifted, and it was left to national governments to act upon the recommendations discussed there. In 1976, the US National Institutes of Health (NIH) issued technical guidelines for recombinant DNA research in line with the proposals, which were generally accepted world-wide as a standard for ensuring laboratory safety. Covering all work that was funded by the federal government, these famous NIH guidelines specified norms for risk evaluation in genetic engineering, for the safe handling of GMOs, and for the adequate design of laboratories. With the help of these guidelines, funding agencies in the US and other countries, as well as national governments, could easily adopt an internationally compatible frame of what to consider risky or safe. However voluntary it was, this was the first instance of a regulation being introduced in order to ensure that biotechnology could be developed.

From 1974 on, researchers and regulators responded promptly to the concerns raised in the Berg letter in an international, collaborative approach to regulating certain aspects of 
biotechnology. They perceived the necessity of rules long before politicians broached the issue. Scientists appreciated that research in biotechnology had huge potential but that this potential would only be realised if controls were put in place. Thus, the new NIH standard was welcomed. Yet, it raised the political question of how to implement regulation on a national level, since countries differ hugely with respect to their scientific landscape. Some countries, like (in alphabetical order) Denmark, France, Germany, the Netherlands, Sweden, Switzerland and the UK had a strong tradition in molecular and cellular biological research and major industrial interests, and some of these 'forerunners' also had an alerted public that would react to the new challenge. Other countries lacked such traditions, interests or a similar level of public alertness.

The solution was to leave it to the scientists to decide. The US debate that led to the moratorium had taken place mostly among the scientific community, and this group constituted the major actor in Europe as well. Since many researchers had, for long, been committed to international collaboration, they reacted in a fairly uniform manner in defining the problem in terms of science based risk assessments. Most of the 'forerunner' countries quickly opted for a voluntary approach based on the NIH guidelines, and advisory committees were set up in these countries in similar ways. Since the emerging public policy issues focused on the perceived health and safety risks, it was no wonder that the different regulatory solutions were strikingly uniform from the practical point of view. The European countries had a common interest in safeguarding the future scientific development of biotechnology, so (voluntary) regulation aimed to provide the conditions in which the new and exciting field could flourish. Scientists themselves, it was felt, should narrow the gap between technology and society by virtue of their technical expertise.

Despite a general impression of uniformity, however, there were already some differences in these early days. Some of the 'forerunner' countries tried to keep the problem strictly within the scientific frame of technology and left the solution to technical experts alone, while others adopted a more inclusive approach, soliciting views from other sections of society. Indeed, it was soon clear that biotechnology implicated issues beyond the purely technical aspects of risk and safety.

\section{From Science to Politics}

\section{Reactions among European 'forerunners'}

Among the first countries to react to the scientific concerns was the $U K$, where the Department of Education and Science had implemented its own moratorium. Research Councils were keen to ensure that appropriate guidelines were introduced in order to allow researchers to return to work quickly. These guidelines were based on the existing regulatory framework for hazards from such sources as chemicals, and they even preceded the NIH guidelines. While the UK did not witness any significant public debate in this period, and though discussions remained firmly within the scientific arena, the members of the Genetic Manipulation Advisory Group founded in 1976 (the term 'manipulation' was changed later to 'modification' due to its perceived contentiousness) were recruited in a very British mode. 
Although they only advised on technical matters, like risk assessment and physical containment levels, not all of them were scientific or medical experts, some were also drawn from trade unions, management, industry and public interest groups. The composition of this committee provided for some information flow into other sectors of society (Cantley 1996, p. 516), but the scientific frame was not questioned. Much as in the US, the media focused on scientific (particularly medical) progress (see Gutteling et al. in this book). Nevertheless, the UK was one of the first countries to introduce a regulation (in 1978) seeking to ensure a safe approach to genetic modification. Under existing legislation, laboratories had to notify the Health and Safety Executive of experiments; scientists were advised on a 'voluntary' caseby-case basis, but they were not required by law to follow the advice, only to submit the information.

Also the Swedish Scientific Committee, set up in 1975 by the Academy of Sciences, was comprised not only of scientists, but also of representatives from government agencies, industry and NGOs. Their tasks were slightly different from those of the British: besides the review of research proposals, they had a mandate to keep the general public informed and to advise the Cabinet. This indicates that the issue was held to be of general concern and not only confined to the scientific community. This perception proved to be a realistic assessment, or, according to another interpretation, it helped to trigger the following events: Sweden experienced the first public debate on biotechnology in Europe when the announcement to build a special laboratory attracted media attention in 1978. For a considerable time, and similar to the US and other European countries, biotechnology had been a story of a promising new technology that focused on the US. Now, surveys showed strong public opposition to the plans, as biotechnology appeared dangerous and morally questionable. The Swedish government's answer to public concerns was regulation. In 1980, biotechnology was brought under existing laws, still following the NIH-guidelines. The Director of the powerful Committee for Industrial Safety and Occupational Health chaired the new governmental Recombinant DNA Advisory Agency, indicating that the new issue had found its place in the existing framework of risk management. A general feeling that trusted public institutions had taken care of the matter allowed public debate to wane; however, it never ceased altogether.

Comparing the British and Swedish experiences, we may identify similarities in that both were 'forerunners' in science; they both saw the need for public and government involvement in the issue; both acknowledged, implicitly or explicitly, that there were legitimate interests beyond the purely technical understanding; and they both set up advisory committees. In the UK this resulted in rapid regulation, while in Sweden it resulted in the first public debate on biotechnology in Europe (in fact regulation did not come until some time later). The difference obviously lay in the fact that in Sweden a special incident (the announcement of building the laboratory) elicited public attention. In the UK there was no such event in phase 1 or, at least, similar events were not covered in the same way, and public debate arose only much later. Such 'key events' of various kinds played a significant role in many countries as they raised public interest and eventually kicked off public debates, in turn leading to regulatory initiatives. However, this happened at different points in time, which contributed to the striking European diversity in the response to biotechnology. 
In other countries, politicians (as well as the public) perceived any problem related to biotechnology as an issue to be resolved exclusively by the scientific expert community. This also resulted in the notion that matters with which scientific expertise was unable to deal were to be considered as irrelevant. France adopted a regulatory approach that came closest to a system of scientific self-regulation. Institutions performing recombinant DNA research were to sign a contract with a research agency promising that they would follow French and international guidelines (Gottweis, 1995, p.150). Although ethical considerations were emphasised early on (Cantley, 1995, p.587ff.), they were to be dealt with only in special committees. This bottom-up approach was complemented by Government's state-centred modernisation efforts. The institutionalisation of molecular biology was guided by a deliberate science-push policy, in line with a traditional understanding of the path of technical innovation. The French regulatory system, with its tradition of long-term planning and strong top-down orientation, succeeded for a long time in keeping the issue within the realms of the scientific and regulatory expert community. In order not to jeopardise this official policy, the French government was reluctant to respond to any concerns on issues other than physical risk.

Switzerland and Germany, which were among the technological 'forerunners' with strong pharmaceutical industries, also followed the path of scientific self-regulation, but initially with less emphasis placed on coordinating state action than in France. As early as 1975, the Swiss scientific community adopted the NIH guidelines and the Academy of Sciences established an Advisory Committee. Also in 1975, the German Research Association founded a Commission for Recombinant DNA. Later, the chemical engineers' association extended their concept of biotechnology to include the 'new genetics'. In 1978, at the same time as in the UK, the German government enacted safety guidelines for biotechnological research. Attempts by the German government to be the first in formulating a draft law for 'the protection from risks associated with modern biotechnology' in the same year triggered resistance by scientific organisations and industry (Brock et al., 1991). Scientists perceived it to be an insult to their freedom of research when government tried to impose regulations on a scientific field. Otherwise, during phase 1, there was little indication of the serious conflicts that would later emerge.

'Latecomer' countries, as opposed to the 'forerunners' mentioned, did not exhibit particular strategies with respect to biotechnology, and consequently adopted regulation only later (this group included the 'periphery' of what is now the EU, namely the Mediterranean countries, Ireland, Finland, Austria, but also Belgium and Luxembourg, as well as Norway12). They either had a less important research base or an industry that had no genuine interest in lobbying for support. Alternatively, they simply followed, after a short delay, the path of the 'forerunners'. As long as there was no public debate or reaction to perceived risks, 'latecomer' countries considered it advantageous to avoid actively addressing this issue and they adopted an attitude of 'wait and see'. Eventually, some of the 'latecomers' adopted strategies resembling those of phase 1 in the 'forerunner' countries, at a point in time when the latter had already reached subsequent phases. As we shall see, others went their own way.

\section{Europe and the US parting}


The debate on genetic manipulation had culminated in the US in 1977, when an increasing number of scientists concluded that the risks had been exaggerated and that the moratorium was a mistake. What had begun as a small group of scientists attempting to act responsibly towards the public, was seen to have spiralled out of control because it resulted in the public perception of biotechnology as a field replete with risks. Consequently, and pointing to the fact that no major accidents had yet been reported, the US scientists started to publicly deny that there were any novel 'biohazards' i.e. any risks that would justify special legislation, let alone a moratorium. Having effectively opened the debate on biotechnology, over the next couple of years the scientific community also managed to secure its closure. At least for the time being, genetic technology ceased to be a hot topic for public debate in the US (if it ever had been one).

At this juncture, the European and the American scenes diverged. At the end of phase 1, when public debate was beginning to wane in the US, events attracting media attention led to new debates in Sweden, and at a later point in time also in Denmark, Germany, the Netherlands and other countries. European countries also took up various issues beyond those of technical risk, thus widening the scope of the debate. It is importantto note that until the mid-Nineties these debates were divers and strictly national, and they were often confined to local contexts. At the EU level, however, the Directorate General Twelve responsible for R\&D (DG XII), accepted the dominant framing of biotechnology as an entirely scientific endeavour, much in line with the US approach (Cantley 1995, pp. 518 ff.).13

\section{Summary}

An initial wave of concern, mainly about laboratory safety, and originating from the scientific community in the US, led to a self-imposed moratorium that subsequently gave rise to the NIH guidelines. Over time, doubts arose about the significance of the initial concerns - and about whether the price to be paid (in the form of self-imposed restrictions) was too high. In the US, the public debate waned after scientists had reassured the public that risks were both marginal and manageable if voluntary guidelines were followed. In certain European countries, public opposition began to mobilise when a particular event or project attracted enough media attention. The conflicts arising often resulted in demands for the regulation of biotechnology under special laws. However, the US example prompted many regulators to abandon any plans for such a law. By 1980, self-regulation by the scientific community, in line with the US guidelines, and made statutory because of links to the existing regulation of other fields (e.g. chemicals), seemed to provide a flexible and sufficient means of ensuring an acceptable safety level for the handling of recombinant DNA. Concerns other than those of technical risk were dismissed as being unscientific or left to be dealt with separately. This arrangement served effectively to assuage public debates in most countries. Consequently, for the regulators the problem appeared to have been settled. But contrary to the situation in the US, it was only a matter of time before new conflicts arose.

\section{Phase 2 (1978-90): Competitiveness, Resistance and Regulatory Responses}


Phase 2 saw the entry of biotechnology into the public sphere. New frames arose, and new debates emerged as it became clear that biotechnology had great economic potential. But at the same time, the issue began to attract the interest of new actors. Starting from controversies over risk, the debates opened up, borrowing arguments from other contested fields in society. Especially when GMOs were grown in large quantities, or were to be released into the environment, biotechnology was discussed from a variety of perspectives and no longer within the scientific frame alone. Political responses themselves were different according to the regulatory styles and policy traditions of each nation. Over time, regulatory events and arguments raised in the various debates influenced each other across borders and boundaries, and biotechnology became a European issue.

\section{Biotechnology Meets Society At Large}

\section{The New Economic Frame}

In phase 1, it was mainly scientists that were concerned about the risks of their daily work in the laboratory. In phase 2, biotechnology had left the scientific laboratories and began to branch out from basic research into applied science. In pharmaceutical, chemical and, later, also in plant breeding companies, biotechnology improved both R\&D as well as production processes. Its promise was to create products that had never before been available, or at least not in such quantities or at such high quality.14 This produced an enlargement in the range of legitimate points for consideration in discussions of regulation. Economic expectations became more important, and in order to speed up the handling of applications, and thus to enhance national competitiveness, there was pressure for regulation to be simplified.

Another factor supporting this development was the general political climate. The Eighties witnessed a 'paradigm shift' according to Peter Hall (Hall 199x), manifested in the rise of conservative governments and the expansion of supply-side economic thinking. International competitiveness became an important issue, and the early commercialisation of biotechnology fits neatly into this paradigm. In this period, unemployment increased in many countries and started to develop into a serious political problem. Competing in the high technology innovation race appeared to be the only means of maintaining established levels of welfare in the face of rising unemployment and strained social security systems. In this context, biotechnology gained the reputation of being a 'key technology' and an 'industrially strategic area' (Sharp, 1985).

Starting in the US in the early Eighties, public attention also shifted to the industrial potential of the technology (Pline, 1991). The press emphasised the importance of biotechnology in a new era of the scientific-technological race. Biotechnology was framed as a lead technology, along with information technology, which at that time had already started to have an immense impact on industrial production processes.15 Accordingly, it was believed that those who missed the chance to be at the forefront of technological innovation would put the wealth of their nation at peril: biotechnology had to be made to happen. Thus, supporters of biotechnology warned national governments not to delay its application by 'unnecessary' regulation. Especially in the US, where commercial biotechnology was most advanced, 
regulation was seen as a threat to economic competitiveness. Research had been going on without incident for several years, and the NIH had continuously modified the guidelines with a view to facilitating R\&D and, implicitly, encouraging the successful application of its results. Small start-up firms, founded as spin-offs from academic research, struggled to develop their techniques while keeping up the promise for new products in order to raise money on the stock markets (Oakey et al., 1990).

Following this imperative, by 1978 the UK government had re-categorised much recombinant DNA work as low risk and advised that it should take place under 'good microbiological practice'.16 In general, while in the Seventies regulation in the form of guidelines for laboratory safety had been brought to the fore, now regulatory efforts were reduced. However, an encouraging regulatory environment was only one element in securing a successful future for biotechnology. Promoters demanded more: namely an explicit and dedicated support strategy for translating scientific insights into commercial products, in other words, to accelerate the speed of the innovation chain. 17

So, support for R\&D gained momentum with the complementary strategy of governments' two-sided approach to fostering biotechnology. In most European 'forerunner' countries, governments funded huge programs to promote research.18 However, paramount for realising the promised potential of biotechnology was support for new firms. As a result, some European governments invested in new biotechnology start-up firms or forged relations between academic researchers and industry. Companies like Celltech in Britain, Kabi in Sweden, but also Novo in Denmark, Hoechst in Germany, and Gist Brocades in the Netherlands embraced biotechnology as a field of basic innovation with enormous economic oportunities. 19

\section{Emerging Debates: Commercial Applications of Genetically Modified Organisms}

New kinds of safety problems arose with the possibility of commercial application. 'Large scale' and 'deliberate release' were terms that came to symbolise the existence of concerns that transgressed the conditions of basic scientific research (Cantley, 1995, p.528).20 In particuar, the regulatory challenges presented by large-scale production had to be reconciled with the desire to support industrial biotechnology.21 The growth of modified microorganisms in large fermenters, as opposed to tiny articles of laboratory apparatus, posed a cnsiderable risk. If an accident occurred, a huge number of GMOs, usually bacteria, would be released into the environment, with unknown consequences. However, there were tools at hand to deal with such risks. The NIH guidelines had already defined adequate containment measures for various classes of organisms according to their potential hazard. The first products, available from the mid-eighties, were biologically active substances like human growth hormone, insulin, interferon and vaccines against an increasing variety of diseases. Other types of products entering the market stage were enzymes for washing purposes and chymosin for cheese production.

The second area of commercial application was agriculture, which implied the release of GMOs into the environment without any containment. There were no blueprints for guidelines at hand, in contrast to the situation with large-scale production. Consequently, uncertainty was much greater, and scientists too had some doubts about their ability to predict 
risks. The opposition of anti-biotechnology NGOs, however, was more far-reaching (see Beck, 1986). They considered the risks posed by the genetic modification of living organisms as 'new', since such organisms could not be encountered in nature. The release of such an organism was seen as an irreversible experiment that was unforeseeable in its consequences. Once deliberately or incidentally released, such organisms could never be reclaimed. In the light of the precautionary principle, 22 opponents claimed that such uncertainty demanded a ban. Proof of the absence of risk was argued to be a proper precondition for the use of GMOs. And, since large-scale production posed the risk of unintentional release, the same argument was advanced for other applications.

Proponents of biotechnology considered the NGO's demands to be illogical nonsense, since the absence of something cannot be proven. They pointed to the fact that every innovation to date had entailed some uncertainty, otherwise it would not have been innovative. According to proponents, in the case of biotechnology in general, and even releases of GMOs, a risk/benefit analysis would show that huge benefits went along with minimal risks. This opened up a second path of argumentation. Yet, opponents also claimed that the new biotechnological products had disadvantages compared to traditional ones, which meant that the risk/benefit relation would always be negative in their view.

The new discussions about the deliberate releases of GMOs emerged across the Atlantic, when in 1982 researchers in the US for the first time sought permission for their release, which was granted after years of litigation and conflict (Krimsky, 1991, pp.113-132).23 The photograph of a worker wearing a protective astronaut-like suit while spraying bacteria on a field became one of the governing images of what the release of GMOs could mean. While the debate in the US waned,24 or became confined to scientific circles, interest was intensified in Europe in a political climate shaped by several other conflicts over technologies. In the early Eighties, some European countries, such as Sweden, Denmark, Germany and the Netherlands, saw frequent public debates about technology, and the struggle over nuclear power was at its height. In a climate in which NGOs and sections of the public were geared to engage in debates, new developments in the commercial application of biotechnology swiftly evoked opposition. For example, when the Hoechst Company announced its plan to construct a plant for recombinant insulin production, this became the German 'key event' and triggered widespread public debate, NGO action, and ligitation.

However, we have to keep in mind that reactions varied from country to country. For example, the question of whether or not GMOs should be released elicited virtually no reaction in France, but lead to a heated controversy in Germany.

\section{Biotechnology as a Sounding Board}

It was not only the risk issue involved in the transition from basic research to applied science that had huge consequences for debates on biotechnology. Once elicited, debates rarely stuck simply to the technology itself. Rather, debates came to inhere in much broader societal discourses. Together with interests in commercial application, those interests focused on biotechnology that ran counter to the kind of innovations the new technology would bring about. 
An example was the conflict over recombinant Bovine Somatotropin (rBST).25 This case sheds light on the fact that, from early on, there was acute sensitivity about applications of biotechnology in agriculture, and this revealed that more was at stake in discussions of biotechnology than the question of risks to the health of man or animals. Here, socioeconomic considerations about the structure of agricultural production were clearly at issue. Opponents considered biotechnology to be spearheading an agricultural rationalisation and industrialisation oriented solely towards economic criteria.26 Although such arguments were dismissed as irrelevant when it came to the approval of single veterinary drugs, these concerns were nevertheless considered implicitly and played a role in the decision-making process (Tichy, 1995).27

Even more fundamental was the debate on medical diagnostics, as this clearly touched on issues of medical ethics. As the German sociologist Ulrich Beck (1988) speculated, such applications would not only permit, but reinforce eugenic sentiments.28 In some (Romanic) countries, ethical considerations had played a role for some time in the discourse among experts and Churches. But Beck's concerns were derived from both ethical and societal considerations, since improved medical diagnostics might have major consequences for health insurance systems and for social solidarity.

Characteristic of this phase was also the fact that arguments were not focused on the different forms of application, but often transgressed the boundaries and conceived of biotechnology as a general entity. Critics tried to decipher, in all applications, the perceived underlying rationale of biotechnology as a technological and reductionist perception of life itself, one that seeks to instrumentalise life for the sake of profit. For their part, promoters tried to demonstrate the contributions to the common good that would emerge from the new methods. They stressed enhanced precision, widening possibilities for medicine, environmental remedies and industrial production. Ethical problems were sometimes acknowledged, but were usually left to expert advice.

Opponents often sought advice from scientists who were opposed to the analytical/ synthetical approach of molecular biology, and they were often to be found within the ecological sciences. Hence, in the struggles over biotechnology, scientific expertise of two different kinds was at hand, either denying the possibility of hazards or emphasising uncertainty and risks.29 This contributed to the bewildering array of lay-people and politicians who demanded 'impartial' expertise from the sciences, since for most of them it was inconceivable that there was more than one version of , objective' truth. Ultimately, this would contribute to the erosion of trust in scientific .

As the debate grew more intense, the argumentation patterns in the controversy became even more concentrated on social and environmental aspects and the implications of the technology than on the technological methods themselves. In dealing with social, economic, ethical and environmental subjects, the frame became enlarged. Along with debating new technological opportunities and risks, the basic relation between man and nature was questioned. And by looking at the performance of the actors involved, the relation between scientific and political elites and the general public came into focus (Kliment, Renn, Hampel, 1994).

The media reported two different stories about biotechnology. Industry, on the one hand, emotionalised commercial applications including large-scale fermenting and deliberate 
release. Exaggerations of future promises were commonplace as companies tried to attract venture capital, despite the fact that only very few of them had an actual product. On the other hand, environmentalists put forward not only risk arguments - whether or not they were substantiated - and abstract ethical considerations, but also concrete and serious doubts about the track record of the chemical and agro-industry and the financial entanglement of senior researchers with start-up companies (Cantley 1995, p.547).

Thus, the image of biotechnology as a potentially controversial technique became established in part of the elite's mind. In phase 1, the critical arguments originated from within the scientific community; in phase 2, all sorts of organisations, including Churches and NGOs contributed to the debate. Biotechnology became a widely discussed political topic, where underlying interests and world-views played a significant role. Also the meaning of 'risk' changed: in phase 1, a technical risk definition was still adequate, whereas in phase 2 critics linked the issue to other contested areas, e.g. reproductive technology, feminism, animal rights, and even the desired path of future development. The argumentation patterns reflected the technology in its social and environmental context. Along with new technological opportunities, new questions were put forward: who should have the profit? And what should the relation among the scientific and political elites and the ordinary citizens be? By transgressing the narrow range of issues that most scientific experts deemed legitimate for discussion, the seemingly 'natural' way of implementing the new technology and entering the next stage in the innovation chain was seriously challenged.

In order to understand the evolving controversies, we have to look at how the political systems in the European countries reacted to this challenge. Not surprisingly, we meet a stunning variety of responses. Clearly, there is no such thing as a standard political response; rather, each country developed its own way of dealing with the emerging challenge posed by different stakeholders' demands.

\section{Political Responses}

Proponents wanted to continue the expert-oriented self-regulatory practice established in phase 1. This was perceived to be sufficient to deal with, what they considered to be, legitimate concerns. After all, according to scientists, genetic engineering methods had been shown to be inherently safe; and they discounted the potential for intentional misuse or remotely possible, unintentional hazards. Critics tried to abolish industry's privilege of selfregulation, which inevitably entailed a conflict between commercial interest and safety, as they argued. They wanted to broaden the scope of regulation to cover all applications, or even to ban the technology altogether.

With respect to both lines of thought, there was major variation across Europe, due to differences in the development of the biotechnology industry and research bases, but also because of differing political situations. Some countries had green parties in their parliaments, or NGOs integrated into the national political system, others had not. The role of Churches had been different, and governments were confronted with public awareness of the potential risks of genetic engineering to differing degrees. Additionally, some, but not all, countries experienced severe economic crises during the Eighties, and the period witnessed the rise of conservative governments and an increased emphasis on economic issues. 
Accordingly, variations in national regulation in the beginning of phase 2 continued or even increased over time.30 The task for each of the governments was to realise the promises of biotechnology as a 'key technology', but the strategies employed differed. Governments did not heed public demands for a ban on biotechnology; rather, they looked for possibilities of integrating concerns in such a way that did not threaten the economic status of national industries or the competitiveness of the research base. They also sought to maintain efforts to support R\&D activities. These political strategies, designed to avoid widespread conflicts, were more or less successful in most countries. This does not mean that, in reality, a national 'consensus' was achieved. Rather, the opposing forces - with some notable exceptions - did not intend, or were unable, to provoke an open conflict fought out in a public arena.31

\section{Countries and Policy Styles}

Within the range of European diversity, some countries provide exemplars of the different types of political response. We can distinguish four (idealised) ways of dealing with the task of regulation and with public concerns:

- exclusive or elite decision-making (as in France);

- co-optation (as in the UK, the Netherlands and Sweden);

- public participation (as in Denmark);

- delegation to the European level (as in most Southern countries, among others).

\section{Model I: Exclusive or elite decision-making}

France had experienced a relatively intensive and controversial debate on nuclear energy, which had even been 'significantly more aggressive' than that of Germany (Rucht, 1995, p.282). In comparison however, public awareness of biotechnology remained negligible. France was the only country among the 'forerunners' that succeeded in maintaining an entirely expert-based regulatory style without the incorporation of public concerns. The partnership between public authorities, industry and research institutes was supported by the recruitment system dominated by the 'Grands Corps', which permitted common orientations and personal ties to develop among the different societal elites. Until 1996, other institutions like Churches, consumer or environmental organisations, never succeeded in making (or never intended to make) biotechnology a controversial issue. In phase 2, this closed regulatory process was not confronted by any public mobilisation as far as biotechnology is concerned.

Like France, the UK had a closed and consensual political culture, supported by the electoral system. But British science and technology policy-making, although oriented towards expert knowledge, favoured a pragmatic case-by-case approach, where the main actors co-operated in the introduction of a series of more-or-less ad hoc regulatory mechanisms through a complex network. 'The British style of policy-making ... tends to be informal, co-operative, and closed to all but a selected inner circle of participants. Disputes are resolved as far as possible through negotiation within this socially bounded space' (Jasanoff, 1995, p.325f.) The 
major difference from France was that this closure was handled in a pragmatic way, with channels provided for the integration of NGOs. Advisory committees to government (a key part of UK technology policy-making) were able to take account of wider public concerns because of their membership (they often included public interest representatives), as well as through their engagement in various forms of public consultation. 32 Thus, government could reconcile the critics' demands comparatively well without jeopardising its elitist decisionmaking style, and without becoming truly participatory. When experiencing early difficulties with the public acceptance of biotechnology, British authorities included environmentalists in the advisory committees. This pattern secured the co-optation of moderate groups to include 'a voice of reasoned dissent that could be internalised without seriously jeopardising the evolution of technology' (Jasanoff, 1995, p.319). Such committees were also flexible enough to adapt to new policies: following recognition of the industrial use of biotechnology, in 1984 the advisory body was replaced, and this marked the shift from a regulatory phase to that of a concrete promotion strategy.

Early in phase 2, the German public was mobilised. This was the peak of a development that began with the student movement of the late Sixties, questioning the traditional path of technological modernisation. Different concerns 'merged together over the years and formed a highly active and politicised movement sector with considerable overlaps by the end of the 1970s without losing its political and organisational heterogeneity' (Rucht, 1991, p.185). Government tried to channel the emerging public debate and refer it back to the scientific experts (Gill, 1991) by concentrating on technical details.33 But these attempts to close the biotechnology debate failed. With the Green Party, debate moved to Parliament, and there an Enquiry Commission discussed (economic) opportunities versus the (technical) risks of biotechnology on a rather broad base. When attempts to ban the technology were dismissed, the Green Party started to mobilise the public (Gill, 1991, p.172). German industry, at first strictly opposed to a special law, over time came to appreciate the need for a clear legal framework as a protection against litigation. The German gene law of 1990 offered, as a partial concession, 'participation on the government's key advisory committee and created a new public hearing process for deliberate release application. These procedural innovations seemed responsive to the enactment. In practice, however, the first hearings deteriorated into administrative wrangles and rhetorical stand-offs that led the government in 1993 to revise the law (Jasanoff, 1995, p.323).

\section{Model II: co-optation}

The situation in the Netherlands was quite different from that in the UK and in France. As in Germany, radical groups had been involved in the debate on biotechnology, and in the late Eighties fields with GM crops were destroyed (van Praag, 1991). But the social support in general for radical political action was low. 'All movements contain important reformist fractions, primarily concerned with influencing decision-making, which therefore attach great importance to a pragmatic bond with political parties, trade-unions and various ministries' (van Praag, 1991, p.312). The Dutch biotechnology policy had always been explicitly twosided: technology stimulation to harness the potential benefits was combined with attention to potential risk and public accountability.34 '... the relationship between (new) social movements and the government (...) differs strongly from countries such as the Federal 
Republic of Germany. In the Netherlands, this relationship must be seen against the background of the traditional bargaining model which has always governed labour relations and the political practice developed during the period of pillarization of subsidising various social groups and, if necessary, involving them in policy preparation. After the initial shock of the various protest manifestations in the sixties, the government soon decided to modify its politics with regard to the.... (different) movements. Co-operation and consultation, rather than repression, were the government's first priorities. ...Up till now, this policy has been rather successful; the Netherlands is one of the least (politically) violent countries in Europe. .... One could say that the Dutch political system is relatively open to new demands and social needs.' (van Praag, 1991, p.311).

In social democratic Sweden, the relatively tough regulatory regime was seen as a barrier to competitiveness and international collaboration despite certain relaxations of the regulations (Sharp, 1985). Concerns still focused on the need to ensure the management of health and safety risks, but in an environment that would not restrict $R \& D$, since technological development was seen as being part, or even the basis, of societal progress. As it became clear that defining parameters for risk and support required a close relationship between the academic and industrial communities, the regulators' answer was to bring stakeholders from all backgrounds together in several scientific advisory committees, thus enlarging the scope of the problem definition, while keeping it under strict control.

\section{Model III: public participation}

Denmark, according to the results of the Eurobarometer-Survey (Durant et al., 1998), had one of the most 'sceptical' publics in Europe. Biotechnology issues were hotly discussed and environmental movements had been important in creating a public debate (Gundelach, 1991, p.278). Yet, in spite of critical attitudes, at first glance public debate seemed to be more differentiated, and Denmark appeared to be the showpiece for public participation. This participatory political approach also reflected the regulators' inclusive political tradition. 'In Denmark ... politicians have been very efficient in taking the wind out of the movements by entering into discussion with the movements and accepting several of their demands' (Gundelach, 1991, p.274). With the consensus conference model, ${ }^{35}$ Denmark succeeded in engaging in a public debate that was deemed legitimate and which could ensure at least public tolerance of biotechnology. In 1986, it became the first country in the world to pass a special 'horizontal' law on genetic engineering, covering various applications in research and industrial production under one single piece of legislation. It largely followed the established blueprint of the NIH guidelines for work with recombinant organisms in the laboratory, but it also provided a means to apply biotechnology on a large scale. Concerning releases, there were certain regulatory idiosyncrasies, which met the critics' demands in a rhetorical way.36

\section{Model IV: Delegation to European Regulators}

In 'latecomer' countries - mostly Southern ones like Italy, Spain and Greece, but also countries at the European periphery like Ireland - biotechnology was not as developed as in the 'forerunner' countries, and public awareness was more or less absent. Hence they could 
choose simply to proceed with the application of the NIH guidelines until such time as the EU developed regulations aimed at harmonising the common European market.37

During the Eighties, as at other times, the aim of most governments was to promote the research base, and there was no need to develop regulatory activities on their own which could have led to the public becoming interested or suspicious. Debates about biotechnology, if they ever arose, remained national, and even in countries sharing a common language, such as Germany, Switzerland and Austria, the situations were entirely

different. Whether or not the public 'caught fire' remained largely a matter of chance, or depended on a mobilising event such as the first release of a GMO, or the construction of a particular production facility. In most 'latecomer' countries, there was no such crucial event during the Eighties.

\section{Cross-Country Repercussions and EU Regulation}

Although debates remained confined to national settings in phase 2, any national regulation such as the German Gene Law - was, of course, not totally detached from what was going on elsewhere in Europe. This piece of legislation, for example, took into account the precedent of the Danish law as well as those of the US, the British and Dutch in attempting to legislate for the entire range of biotechnological applications. The German law also built on the OECD38 'Recombinant DNA Safety Considerations' (OECD, 1986, see below), and mirrored the discussions on the EU level of proposals for several special directives on biotechnology.39 In fact, the EU proposals on the idea of separate legislation may have weakened those forces in Germany that still resisted a special national gene law.

Conversely, the regulatory developments in Germany also had repercussions in other European countries. For example in France, during the late Eighties, policy-makers attempted to counteract what they perceived as rising public distrust40 (Gottweis, 1995, pp.394-402). What happened in Germany was considered anathema to the promoters of biotechnology. But, unlike the British and German governments, the French did not pass any legally binding regulations, especially since a regulatory decision was soon to be expected at the EU level. Rather, they followed a 'business as usual' strategy and succeeded in keeping matters within the realm of expert decision-making.41 From 1986, the Commission Génie Biomoleculaire at the Ministry of Agriculture promoted the objective of France becoming the leading European country in the field of GMO releases. Indeed, the number of French releases did increase, and by the end of 1998 they almost doubled those in Italy, the country with the second largest number of releases in Europe (UBA, 1999). Only in Canada and in the US were there more releases (OECD, 1998).

\section{Regulation and the Economic Frame}

The European Commission had long been watching the emergence of different regulations in European countries. They feared that this trend would jeopardise the common market in a future field of high technology, and over the Eighties they made serious efforts to define a common European legal standard (for reviews see Cantley, 1996; Galloux et al., 1998). The 
first such attempt, a proposal of 1979 by DG XII, had been abandoned because at that time non-regulation was the favoured option (Cantley, 1995, p.526; Galloux et al., 1998, p.180). Since methods of biotechnology had not resulted in any apparent negative incidents, the intention was not to endanger the 'key technology's' promise of industrial growth and new products.

In response to changing perceptions of the need for regulation, in 1982 the Council recommended the development of oversight structures. The general feeling over the next three years was that new applications would not pose insurmountable problems as far as safety was concerned. In order to enhance European competitiveness, ${ }^{42}$ the Commission put more emphasis on a coherent strategy to promote R\&D through DG XII and its Biotechnology Steering Committee.43 However, with the small budget available, this proved to be difficult for the Commission, and industry hesitated to co-operate. 'At the end of the Eighties, the Commission sees itself confronted with the fact that its aim, namely to promote co-operation between public and private research and to construct a European research network, could not be reached' (Bongert, 1997, p.127, own translation).

\section{Extension of the frame of regulation}

The political efforts for the promotion of R\&D changed in the mid-eighties. Paramount was 'the entry of environmental interests into the policy debates on biotechnology (...), as the public authorities at national and Community levels interpreted their general responsibilities for the protection of the environment in relation to the challenges of the new processes and products resulting from biotechnology.' (Cantley 1995, p.546). This marked a major widening of the scope of what were perceived to be legitimate problems involved with biotechnology regulation. Although the 'precautionary principle' was not explicitly adopted, the environment became a focus of attention, along with economic and agricultural interests, while the question of workers' protection was still unresolved. The views of the 'sounding boards' in the individual countries were heard in the European Commission.

This was even more the case with the European Parliament, which in 1985 came up with a view more extreme than that of the Commission in that it demanded special regulation.44 In the same year, the Commission set up a committee with members from several DGs (Galloux et al. 1998, p.181), with the aim of reviewing existing rules and determining whether they adequately dealt with commercial applications. Its composition (representatives of the rival DGs for industry, Social Affairs, Agriculture, Environment and Science, internally competing for influence) suggested a broader understanding of the issues at stake both in terms of the direction of commercial application and of environmental concerns. At the same time, an amendment to the Chemicals Directive provided a blueprint for much of the possible biotechnology regulation. 45

\section{The way to the EU-Directives}

1986 proved to be a "hinge year" (Cantley, 1995, p.549). The first genetic engineering law, passed in Denmark in order to provide an overarching legal frame for the activities of biotechnology research and industry, put the Commission under pressure to act. The German 
Enquiry Commission, influential across the borders of the country, also had the implicit aim of devising a national biotechnology law. Both the Danish and German initiatives, as well as the European Parliament's report, stressed the need for special legislation.

On the other hand, both Britain and the Netherlands felt comfortable with their pragmatic approach under existing sectoral legislation. They received backing from the US, which defined competencies among government agencies under existing legislation in their "Coordinated Framework for the Regulation of Biotechnology". In the same year, the OECD issued its 'Recombinant DNA Safety Considerations' (OECD, 1986) introducing recommendations for the risk assessment of GMOs, e.g. the 'step-by-step' principle and the idea of 'Good Industrial Large Scale Practice (GILSP)', while postponing guidelines for deliberate releases. The OECD report was in line with the US Framework and held strongly the position that 'there is no scientific base for specific legislation to regulate the use of recombinant organisms', which was also the way sectoral DGs of the European Commission, as well as industry, preferred to see the issue. However, inadvertently, the report helped to pave the way for the viewing of recombinant organisms as constituting a distinct category.

The question of whether a transgenic organism should fall under special regulation solely on the grounds of its genetic modifications, and irrespective of the type of application, was hotly debated. It is still a moot point whether such a 'horizontal' regulation is adequate, as opposed to a 'vertical' one for each product according to its properties. Although industry and scientists repeatedly denied the need - and the feasibility - of a special regulation for GMOs, the Commission finally proposed a 'horizontal' regulation in a 'Community Framework for the Regulation of Biotechnology'. The reasons for this step (see Cantley, 1995, p. $550 \mathrm{ff}$.) were threefold and may be conceptualised in terms of harmonisation, risk reduction and dealing with uncertainty. Firstly, the Common Market was to be protected from idiosyncratic national regulation. Secondly, the intention was to universally apply appropriate guidelines for containing levels of production. Thirdly, there was still uncertainty about the criteria for the risk assessment of GMOs to be released to the environment, so a case-by-case approach was designed to systematise the accumulation of experiences.

Clearly, one additional, and openly admitted, aspect of the pressure for regulation was 'public concern', in part a spillover effect from other areas of technology where accidents of an unexpected nature or scale had occurred.' 46 In line with the European Parliament's position, and rhetorically fortified by public concerns, the Commission decided to issue a regulation on GMOs. The proposals for the Directives on Contained Use, as well as on the Deliberate Release and the Placing on the Market of Products, exclusively dealt with GMOs.47 So, although other Directives or drafts had been issued that were more sectorally oriented,48 this approach was abandoned in favour of a more horizontal one.

Industry strongly opposed such horizontal regulation, which they feared would lead to the 'stigmatisation' of the technology of genetic modification. Consequently, the proposals prompted harsh critiques from industry and scientists. These critics were supported by the US, which claimed that there was no scientific basis for regulating GMOs as a special category; that the Directives would hinder R\&D; and that they would introduce non-tariff trade barriers on future products.49 The opposition prompted the EC to construct the Directive on Deliberate Release and the Placing on the Market (which became known as Directive 90/220/EEC) in such a way as to facilitate future 'sectoral' legislation (in spite of 
the 'horizontal' scope of the proposal). The Commission immediately started the work on formulating such legislation for 'novel food'.

Two opposing demands had to be balanced. On the one hand, the European Parliament as a representative of a fictious 'European Public' conveyed the plea for a very cautious approach following the public unease expressed in several member countries, where fears of long-term and indirect effects clearly played a role. On the other hand, science and industry demanded a 'purely science-based' approach focusing only on organismic and product properties, in order not to jeopardise innovation by regulatory demands that remained ambiguous to many. Industry wanted a narrowly defined legal framework so as to enter the race towards the application of a 'key technology'. They were sympathetic to the explicitly de-regulatory US approach of officially relating the degree of regulation to the amount of 'objective risk' posed by the organism.

The political solution seemed to be to stress uncertainty, and the Commission defended the need for a special regulation with the argument that the technique was novel. So the purpose of the regulation was announced to be pro-active (i.e., put in place before any accidents had occurred), in accordance with (at least a certain understanding of) the precautionary principle. The Directives were definitely not enacted on the basis of proven risks from the methods of genetic engineering; rather, the rationale was to use discretion until more experience was gained and regulation could be relaxed.50 By emphasising uncertainty, this regulatory solution tried to force together two apparently incongruent approaches to risk assessment, namely one that built on scientific evidence ex post, and one that built on scenarios of hypothetical risks ex ante. It also acknowledged the dual nature of the 'biotechnology problem' as being technical as well as a matter of public perception, without openly adressing issues beyond risk that could not be dealt with by scientific experts. This artistic and delicate balancing act attempted to bridge the gap between the different regulatory styles and public attitudes in various European countries, in order to provide a unifying framework for future technological innovations. Since the stakes were set this high, it was no wonder that difficulties later arose.

\section{Summary}

Phase 2 saw the diversification and extension of both biotechnology and the debate surrounding it, as it became clear that the new methods could be applied in various fields and contexts. The argumentation reflected two lines of thought prominent in the Eighties. On the one hand, the economic exploitation of research results (as of anything else) was prevalent in a climate shaped by the increasing dominance of supply-side and market economic thinking. On the other hand, technology critiques placed biotechnology on the list of contentious technologies, together with nuclear energy, that were considered to be playing a crucial role in the 'risk society'. Uncertainty about both possible or perceived risks, and promises of economic opportunities led some European governments to 'balance chances and risks' via national regulation. The European Commission recognised several challenges, all of which highlighted the need for unified conditions in the application of biotechnology. Firstly, industry demanded a defined legal framework for their activities. Secondly, national regulations threatened to jeopardise the Common Market for new products. Thirdly, since 
public opposition in mostly Scandinavian or German-speaking countries supported the demand for a special law, there was a need for compromises in order to contain the critique and to prevent its spread.

\section{Phase 3 (1990-96): European Integration}

When the European Community issued its biotechnology Directives, this was an attempt to arrive at a consistent and homogeneous regulation across the EU. The aims were to prevent the passage of idiosyncratic national laws that would jeopardise the implementation of this key technology in a common market, and to provide universal safety standards. Aside from this, the Directives had a variety of impacts in a period in which the EU was considerably enlarged, and when biotechnology regulation became an issue hotly debated across the Atlantic. Although the homogenisation of regulatory approaches proved to be difficult, public debates waned as biotechnology proceeded and became entrenched in science and the economy.

\section{Directives}

In 1990, as a result of long-lasting deliberations on various levels, the European Commission passed a set of Directives on biotechnology.51 The Contained Use Directive imposed a categorisation scheme for micro-organisms and the split between the application of such organisms in 'small scale' (e.g. for research purposes) and 'large scale' devices (e.g. for production). The Deliberate Release Directive rendered mandatory the principles of 'step-bystep' (from laboratory experiments over small research releases to releases of a large number of organisms and, finally, commercialisation) and 'case-by-case' (which implied that each release application had to be considered separately and, although some provisions for a later exemption were made, there was no categorisation). Permissions for the commercialisation of products were granted Community-wide, while permissions for releases remained within national competencies. The Directives did not permit socio-economic criteria to be taken up during the assessments of planned releases or products to be commercialised, only risk issues were intended to be dealt with. This should have served to restrict the range of permissible arguments and to keep the regulatory process firmly within the scope of scientific risk assessment. However, it turned out subsequently that this expectation could not be entirely fulfilled. 52

This program was, in fact, a compromise. Although influenced by public debate, it fell short of a comprehensive regulation that took into account all the concerns that had been voiced for some time in the various countries.53 The Directives provided a legal framework, but industry was not very enthusiastic because it perceived the scientific base of the technologycentered regulation to be flawed, and it feared difficulties in implementation as well as an 'unnecessary burden' for biotechnology. Yet, despite the shortcomings perceived by critics, and the reluctance of the Commission to see the Directives as a final piece of legislation, their importance was enormous. 
Now biotechnology had become a truly European matter. Until then, problem awareness among scientists and regulators had frequently been triggered by developments in the US. Public debates, on the other hand, had arisen almost exclusively in response to certain national events triggering a reaction in the media and raising the interest of NGOs.54 The relative failure of the European Commission to create a Community-wide research network by the end of the Eighties had mirrored the national preoccupation with the research base as well. Hence, before 1990, matters of biotechnology had largely been either transatlantic or national issues in the 'forerunner' countries and non-issues everywhere else. The Directives marked a significant shift, since the intervention of the EU in the regulatory process had consequences for all EU members as well as for other countries.

- The 'forerunner' countries had to adapt their national regulations to the new European standard.

- Other member states of the EU had to adopt the regulation of a hitherto unregulated field.

- New member states had to implement the European regulation.

- After the collapse of the Soviet system, Eastern and Central European states became liberal democracies and developed market economies. As part of their drive towards membership, they adopted relevant EU regulations.

- In order to prevent future trade wars due to 'non-tariff trade barriers', when GM products were to be placed on the market ways had to be found to reconcile the Directives with the US and Canadian way of (de-) regulating biotechnology.

\section{Impact of the Directives on European Countries}

\section{'Forerunners'}

In the 'forerunner' countries, over the years rules had been set up in a system of national interest intermediation. The delicate balance of power between the various actors arose from written and unwritten rules and structural conditions varying from country to country. These rules and conditions changed when regulations started to be negotiated in Brussels instead. The strategic balance in biotechnology conflicts changed dramatically thereafter. Interest groups lost their influence unless they joined European organisations, where there were different rules and where different actors had their say.

In general, a multi-layered regulatory system like the EU tends to favour more potent actors such as industry, since they have better ressources to act on various levels (Bandelow, 1997). Consequently, the shift of the decision-making power to Brussels had a negative impact on the influence of national NGOs, whose resource base was weaker than that of industry. The latter radically re-organised their lobby apparatus in Brussels in the early Nineties, creating a new common organisation called 'Europa-Bio' that served to increase the visibility of their point of view for the Commission and other actors. Consumer and environmental organisations were much slower in securing representation on the European level. This might have been an additional reason why regulation in phase 3 primarily followed industry's 
interests, and why regulatory changes were oriented at de-regulation rather than at public concerns as communicated by NGOs.

The Deliberate Release Directive mentioned the possibility of public participation in national decision-making on some issues, but this was not mandatory and was implemented in only a few countries. Jülich (1998, p.56) analysed the formal possibilities for participation in such processes and distinguished two groups of countries. On the one hand, the Netherlands, Luxembourg, and, somewhat differently, Denmark and Norway (not an EU-member, see below), but also new members of the EU like Sweden and Austria offered guaranteed channels for public participation. In other member states like Belgium, France, the UK, Ireland, Italy, Portugal and Spain, the opportunities for the public to get involved in decisionmaking processes were restricted to a minimum. Germany belonged to the first group until 1993, when the revision of the gene law restricted participation.

The Directives elicited different reactions in each member state. In some countries, the implementation entailed stricter rules or even initiated regulation, in others the existing regulation was relaxed. Some countries felt the necessity of emphasising areas that were not formally regulated by the Directives, for example, ethical considerations, but did so by means of committees etc. and not by law. Thus, though EU regulation was confined to scientific assessments of risks to health and the environment, this did not prevent the transgression of risk issues in public debate and even as a subject to be dealt with by official institutions.

The answer of the $U K$ to the Directives, beyond some legal changes, was the establishment of an Advisory Committee on Releases to the Environment (ACRE). The UK's flexible political mode also allowed for adaptation to new questions that were not dealt with by the EU Directives: in 1991 the launch of the Nuffield Council for Bioethics signalled the increasing importance of ethical issues. Since then, a plethora of new Advisory Committees to Government has been created in order to deal with ethical and social issues arising out of particular medical applications.55

In Denmark, the most important change in the Genetic Engineering Act, brought about by the implementation of the Directives, was the endorsement of the EU approval system for marketing GMOs, replacing the general prohibition of releases. It demanded free marketing of all products approved in the EU, (rhetorically) balanced by environmental guarantees. After the revision of the Danish regulation the political and public activities surrounding biotechnology calmed down. It appeared as if Denmark had found a level of regulation that was acceptable to most actors; however, a certain frustration on the side of the opponents may have persisted. Later on, this temporary frustration manifested itself in renewed opposition.

In France, the Directives forced a stricter regulation than before and ended the particular French method of scientists 'self-regulation. Genetic engineering as a topic found its way into the political debate, but the French system was also confronted by new questions. As in Britain, problems of bio-ethics officially entered the political arena, although they were not formally regulated. Ethical issues had been debated for a considerable time, and French contributions to this field had been influential both on the EU level and within UNESCO.

In the Netherlands, some adaptations to the existing laws were necessary, but this did not evoke too much public interest compared to the advent of the first 'transgenic ${ }^{56}$ animal, the 
bull 'Herman'.57 In 1992, not in immediate response to the Directives, but shortly after they had been implemented, this event pointed to a shortcoming in the Deliberate Release Directive: its inadequate treatment of transgenic animals. This case elicited a heated public debate. It became clear that there were things at stake other than risk-benefit calculations, such as animal rights and their intrinsic dignity, which many considered were being violated by genetic manipulation.58 The political reactions within the pragmatic and open tradition of policy making in the Netherlands consisted of Parliamentary interventions, technology assessments, 59 and the establishment of a new Ethics Committee.

In Germany, the European Directives had a considerable impact upon national regulation. Soon after it had been passed, the German gene law was criticised as being too strict and a threat to competitiveness. Promoters of biotechnology saw the Directives as a chance to get rid of quickly some of the most unwelcome paragraphs. The 1993 revision of the gene law, in complying with the Directives, led to considerable deregulation.60 In the early Nineties, debates saw a shift in focus from environmental problems to economic perspectives (Gill et al., 1998, p.22), and Government eventually succeeded in linking biotechnology and economic perspectives under the frame of competitiveness. Consequently, over the Nineties, Germany became the most prominent promoter of deregulation at the European level.

\section{'Latecomers'}

Before 1990, biotechnology regulation was perceived as a problem mainly in the 'forerunner' countries. Yet, after the Directives had been passed the situation changed, especially in the Mediterranean countries, where the public had hitherto taken hardly any notice of biotechnology. However, developments were not at all uniform. Although public debates comparable to those in 'forerunner' countries could still not be observed after the implementation of the Directives, over the Nineties GMOs slowly became an issue in Greece, also involving international NGOs at the beginning of the debate. The situation in Italy was different, where the issue was hardly on the agenda, although the Catholic Church had argued publicly against biotechnology. The impact of the different economic situations in each country was more decisive for the position of biotechnology than was public debate. In Greece, EU programs and co-operation increased the funding and strengthened the position of biotechnology, while the crisis of the pharmaceutical industry in Italy during the same period slowed down its development.

\section{'Newcomers'}

The European Directives also became binding for the new member countries Sweden, Finland and Austria, who joined the EU in January 1995. The situation differed among these countries, and between them and Southern Europe. In Finland, the gene law passed in 1995 closely reflected the EU regulation. This law, however, did not involve a simple adoption of EU policy, but resulted from extensive discussions between governmental bodies and a plethora of different institutions such as universities, trade unions, NGOs, etc. The openness of the regulative process was a reflection of the intentions of official bodies rather than of 
public pressure, since biotechnology had never been a subject of public or political debate in Finland.

This contrasted with neighbouring Sweden, where the first public debates about biotechnology had taken place in the Seventies. As in Finland, NGOs and a wide variety of interest groups were heard in 1994. The Swedish gene law exhibited a substantial difference to other European regulations in that it also considered ethical aspects. Other attempts to establish stricter regulation failed. Nevertheless, in spite of the generally critical attitude of the Swedish public towards biotechnology, the debate receded once more after the enactment of the law in 1995.

In Austria, the European Directives had already been integrated into the national regulations before Austria joined the EU, solving the conflict over whether or not a specific law was necessary. A parliamentary enquiry commission formed, based on the German example, with the task of anticipating tacit public concerns. Eventually, however, industry interests became more influential, as reflected in the law of 1994. The Commission's work had hardly any impact beyond the integration of a paragraph on the 'social sustainability' of products. This raised doubts about its compatibility with the Directive 90/220, since it also employed a socio-economic criterion (Seifert \&Torgersen, 1996). Such criteria were perceived by the EU as raising non-tariff trade barriers that were in opposition to the overall aim of the Common Market. Since the Austrian paragraph on social sustainability was irrelevant in practice, it remained in the law.

Although the Norwegians decided in a referendum not to join the EU, Norway remained a member of the European Economic Area, which required that it comply with the Community's biotechnology regulations. Part of the Norwegian law was in even more striking contrast to the Release Directive's focus on scientifically assessable risk issues only than the Austrian social sustainability criterion. The Norwegian law demanded that the use of GMOs take place in an ethically and socially justifiable way, and that special emphasis must be given to the societal benefit and the contribution to sustainable development.61 Being a 'latecomer' compared to its neighbours Sweden and Denmark, Norway thus adopted the most restrictive gene law in Europe. Obviously, industry interests were unable to counter such moral considerations and national peculiarities (Nielsen, 1999).

\section{The New Democracies}

Phase 3 also saw the decline of the Soviet system and a new political order in Europe. The general situation switched from post-war to post-cold-war, and circumstances in East-Central and Eastern Europe changed dramatically. As a consequence, former soviet 'satellite' states adopted the Western system and tried to become members of the EU. Whereas most of them had followed a US style of regulation, applying guidelines inspired by the NIH, it now became necessary to adopt the EU Directives. Thus, in states associated with the EU (the Czech Republic, Poland and Hungary), the Directives led to a re-orientation and served as a model for national regulations.

The Czech Republic had no law on biotechnology until 1998, but when joining the OECD it agreed to introduce regulation within two years based on the EU Directives 90/219 and 
90/220. In Hungary, the competent authority secured EU conformity by explicitly following the OECD guidelines. In Poland, regulation started earlier with a Patent Law (1993, reflecting the influence of US views) and the Biodiversity Convention (1995). In 1997, Poland submitted the first draft of a new biotechnology law on the basis of the Directives, to be implemented with the assistance of international organisations (OECD, UNEP and UNIDO62). In all three states, there were no signs of substantial public or political debate on biotechnology. Regulation was left to experts, whose role was questioned neither by domestic NGOs nor by a concerned public.63

\section{Political Implications}

\section{US Point of View: Product Versus Process}

From the American point of view, European regulation was perceived to be process-oriented, since biotechnology as such was regulated in the Directives, irrespective of what kind of product would result from the process (i.e., the technology) involved. The American position was that it is only the product that can be regulated - irrespective of the process applied in its production. This, they argued, was essential to obviate discrimination against novel technologies. The complicated US system of diverse regulatory rulings and various authorities with competence in this area closely mirrored this attitude. Yet, the EU insisted that their approach was not actually process-based. It was claimed that, because there was not enough experience with the new technology, as a temporary measure "horizontal" regulation had been put in place. The EU argued that it expected the horizontal regulation to be replaced, in due time, by sectoral or 'vertical' laws according to the type of product.64

The US was constantly suspicious that the EU would introduce forms of regulation not based upon "sound science" (i.e. on evidence of harm), but rather on a doubtful precautionary principle open to voluntary and unpredictable interpretations. By and large, the US position was that the products of modern biotechnology were not substantially different from traditional products. And by invoking this claim, under the heading of de-regulation the US had started, early on, to exempt certain crop plants from the requirement of obtaining permission prior to release. This was hardly acceptable to the EU with its case-by-case principle. Marketing authorisations that proved virtually unobtainable in the EU were more readily granted in the US. Consequently, the EU was accused of protectionism, because the products in question could not be proven, by 'sound science', to pose any significant risk. Hence the US perceived any objections posed by the EU as attempts to protect their internal market from US imports. The manifestation of these different regulatory styles in the EU and the US, respectively, led eventually to a renewed public engagement in phase 4.

\section{Problems Integrating European Diversity}

However, the European stance on GMO releases and marketing conditions was by no means as uniform as it appeared to the US. There was profound variation in how the obligatory risk assessment was performed; what factors were considered; what 'familiarity' meant; how the step-by-step principle was interpreted; and how to proceed on a case-by-case basis in the face of an increasing number of release applications (Levidow et al., 1996).65 National regulators implementing the EU-Directives had to establish their own normative standards and in doing 
so they made implicit value statements (von Schomberg, 1998). Hence, strong national differences persisted in spite of the existence of common EU regulations. Disharmony was aggravated by different regulatory cultures in the EU member countries, for example with respect to the disclosure of data from the application files.66 The Commission, aware of the implementation problems, created a high-level inter-DG Biotechnology Coordination Committee in 1991 in order to oversee the implementation of the Directives. This powerful committee proved to be open to requests for a flexible revision of the regulation, 67 'according to technical progress, easing administrative requirements' (Galloux et al., 1998, p.181).

\section{Debates Waning: Towards Acceptance}

Despite the continuing national differences, the EU regulation contributed to a calming of the debate on biotechnology in most of the European countries. The economic side and the frame of competitiveness seemed to have suborned public concerns.

Progress in medical applications, which had become generally accepted, was one of the reasons why the public opposition cooled in many countries where biotechnology had been vigorously contested. It was clear that such medical progress was intimately linked to various areas of biotechnological research. A range of highly welcome new drugs and vaccines had emerged over time. Forensic identification of suspects had made huge progress and had been accepted by courts of law; and in several spectacular cases such methods had led to the identification and sentencing of criminals. The Human Genome project made great progress during the Nineties in developing methods of establishing the base sequence of various organisms and - ultimately - of the human genome. Although in the US voices warned of the societal implications for medical insurance of the newly developed predictive medicine, this triggered less concern in Europe with its public health systems providing universal coverage, so that debate relating to this problem was confined to academic circles.

Aside from medicine, there were a handful of biotechnological consumer products that had entered the market in some countries.68 In general, applications that appeared to be of advantage for the consumer seemed to have gained general acceptance by 1995 . When a legal basis had been created that officially satisfied the formal regulative needs within a scientific frame of risk assessment,69 the first products were sold on the market. Hence, existing regulation (at least in the UK) succeeded in ensuring that innovative products could enter the market.

As early as 1995 the first 'genetically engineered' food product, a canned tomato paste made from transgenic fruit, was sold in the UK by two supermarket chains. For the first time, consumers were directly confronted with such products, albeit in a very small market segment. Even when labelling was not statutory, the companies selling the tomato paste labelled voluntarily, arguing that the consumers have the right to choose. These market releases, for the first time allowing consumers to choose between GM and traditional products, did not elicit any public debate in the UK or elsewhere, and the products sold well. Although survey results indicated persistent public unease towards biotechnology (INRA, 1993; Macer, 1994), it seemed that the conflict had lost its ferocity. 
However, the picture was more complicated and could not simply be explained as an adaptation process, 'narrowing the gap' between society and technology. In countries like Germany, 'green' issues had lost some of their appeal in favour of efforts to create jobs, but this was a superficial development. The themes remained in the vocabulary and, as further events showed, also in the peoples' minds. What was actually observed (as, for example, shown by the 1993 Eurobarometer survey, INRA 1993) was a bifurcation in the public's attitude towards biotechnology: on the one hand, applications that led to new treatments, drugs and vaccines were now rarely disputed; on the other, agricultural applications continued to arouse suspicion.70 Although, by 1995, the progress of biotechnology in agriculture appeared inexorable,71 general diffusion conditions for companies engaged in agricultural biotechnology became more difficult. 72

\section{The Biotechnology Industry}

Not until the early Nineties did biotechnology emerge as a 'key technology' of economic significance. New developments were now being fed into the innovation chain without reference to public debate, especially in the US which had taken a substantial lead.

These years were characterised in many European countries by the aftermath of the late Eighties recession; the ever-increasing dynamics of globalisation; and a strong focus on technological innovation. This also led to the emergence of a 'biotechnology industry'. Up to then, pharmaceutical companies and producers of agrochemicals had strong links with organic chemistry. Now, links were being established between the pharmaceutical industry and seed producers, since both depended upon biotechnological methods, the patenting of genes (this was of increasing importance), and both were facing rapidly increasing costs for R\&D. This resulted in mergers of companies globally engaged in the pharmaceutical and seed sectors. These companies' engagement in particular countries was said to show the latter's competitiveness. In official language, anything that jeopardised efforts to sustain or attain this degree of national competitiveness was to be assiduously avoided. The state's role was perceived to be restricted to providing a congenial environment for industrial performance, and it was no longer considered appropriate for the state to promote other societal goals when regulating biotechnology (Bongert, 1997).

Meanwhile, the biotechnology industry underwent massive expansion. From 1993 to 1996, the numbers employed by that industry more than doubled, although they were still small in comparison to more traditional sectors. The number of patent applications increased sharply between 1990 and 1996, and the sector expected a growth rate of 20\%. Nevertheless, European industry still lagged heavily behind that of the US. This was largely because of structural weaknesses: from the industrial and economic point of view there was 'insufficient collaboration between academia and industry, lack of coordination of research between EU member states, (lack of) shared access to resources and infrastructure, and inadequate venture capital.' (Galloux et al., 1998, p.177). The aim of the EU's policy was to obviate these shortcomings and to narrow the gap between the EU and the US.

This disparity was especially pronounced in agriculture. In the US and Canada, but also in China, GM crop plants, such as maize, tobacco, oilseed rape and cotton, began to cover everincreasing percentages of the total agricultural area.73 Aside from the more favourable 
regulatory climate in such countries, the EU also suffered because the sorts of plants that had been developed were most suited to large-scale agricultural systems like that of the US, and were less suitable for the small-scale production typified by many European countries. Only France and neighbouring Spain were expected to become significant producers of transgenic crops, with other countries lagging behind.

\section{Summary}

In phase 3, all EU member states had implemented national regulations. The political elites were able to handle biotechnology within their scientific and economic frames, and these became more and more dominant. The EU made attempts to homogenise the rules for the application of biotechnology in order to create a single Common Market for the products to come. This proved to be more difficult than originally expected, especially since the Release Directive did not resolve, once and for all, national differences in thinking as to how to proceed with risk assessment etc. Nevertheless, the Directives created a compulsory frame which all member countries had to adopt, and which non-members also took as a reference point (especially because some of them subsequently sought to become full EU members). The shift of decision-making competence to Brussels led to a new power balance in favour of industry. Public debate waned in most countries due to other problems that had emerged after the collapse of the former socialist empire and in the light of increasing pressure from globalisation. Public resistance against biotechnology, as such, more or less waned. However, this was not due to an overwhelming acceptance; rather, the applications were now being differentiated in the public mind. Thus, medical applications were more or less welcomed, whereas agricultural biotechnology was still not so well received. This development was intensified after the marketing of the first commercial food products made from GM commodity crop plants.

\section{Phase 4 (1996-): Renewed Opposition and Consumers' ${ }^{6}$ Distrust}

\section{The Backlash}

In phase 3, economic competitiveness and European harmonisation had been the dominating perspectives, and the division in perceptions between medical and agricultural biotechnology, along with the shift to other concerns, had led to a calming of the debate. In phase 4 , the issues at stake diversified again, and debates that had been considered closed re-emerged. The importation of the first GM food crops from the US in 1996 marked the division between phase 3 and phase 4, as consumer products of biotechnology reached the market stage. This trigger event led to renewed public and NGO protests. Later, when new cloning techniques impinged upon ethically sensitivie issues, a wave of concern about the disparity between what was technically possible and what was ethically defensible spread across the globe.

So phase 4 brought a double challenge: on the one hand, renewed conflicts about health risks combined with a struggle for consumers' rights, and on the other hand, deep ethical concerns about the transgression of boundaries affected the image of experimental biology and also biotechnology. Essentially, the issues upon which these conflicts were based were by no 
means new, and their outline was already visible during phase 2 . But the vigour and the rapid spread of the newly arising debate had serious implications for individual countries' policies as well as for those of the EU, and especially for the relationship with the US.

Notwithstanding the European debates, biotechnology had become a global issue. International trade as well as the struggle for securing intellectual property rights became the most important fields of conflict between the EU and the US on the one hand, and between the Industrialised and the Third World on the other. Biotechnology had finally, and undeniably, acquired the status of a 'key technology'. Ironically, as soon as biotechnology began to take off, the term itself began to be replaced by other less contested but more comprehensive descriptions.

\section{Prelude: BSE and the Loss of Trust in Experts and Regulators}

One reason why the evolving conflicts over food issues became so ferocious was the earlier scandal in the EU over BSE74. This was totally unrelated to the issue of GM crop plants, but it set the scene in terms of consumers' concerns about food safety.

A few months before the first arrival of GM soya in a European harbour in 1996, the British Government conceded, after years of rumour, that there might be a link between human Creutzfeld-Jakob disease and Bovine Spongiform Encephalitis. This led to a collapse in the beef market and a ban by the EU on British beef. The main impact of the ensuing 'BSEcrisis' was a growing distrust in scientific experts and political regulators in matters of food safety, since they had been reassuring the public for a long time that there was no evidence for such a link. Consequently, regulators had to change their way of dealing with risks: they acknowledged that regulation could not be left to industry, contrary to the approach preferred by the UK government, and they were forced to accept the fallibility of expert committees.

The UK government and the European Commission were harshly reproved for their handling of this scientifically controversial issue. In 1997 the European Parliament criticised the secretive decision-making processes and the complex and undemocratic system of scientific committees. Threatened with a vote of no confidence, the Commission conceded a strengthening of consumer representation in DGXXIV (Consumer affairs) and more transparency, indicating increasing Parliamentary influence vis-à-vis the Commission. (Baggott, 1998, p.70ff.)75

Critics in some countries quickly asserted parallels between the BSE scandal and the way in which GM food products were entering the market. The issues were obviously scientifically unrelated, but opponents considered them both to be consequences of industrialised agriculture. At the same time, organic farming began to leave the small circles of ecosectarianism in some Central and Northern European countries, and emerged as a counterpoint to industrialised agriculture and biotechnology. Products from organic farming could be bought in ordinary supermarkets and served a new consumer interest. This paved the way for later co-operation between NGOs and retailers which feared consumer boycotts.

\section{Soya and Maize: The European Labelling Debate}


The soya case changed the frames of the regulatory debate away from an emphasis on scientific risk assessment towards finding ways to deal with consumer interests. When the importation of GM soya and maize from the US to Europe began some months after the outbreak of the BSE-crisis, trust in experts who had consistently reassured the public about food safety had already been shaken. The assumption that consumers would generally accept GM food (were it available) proved to be wrong in spite of previously successful market introductions into the UK.

After the EU had granted an approval for the US seed company Monsanto's GM soya, in the Winter of 1995/6, the first actual imports from the US arrived in November 1996. Obviously in an attempt to create facts, the US-grown modified soya had been mixed up with conventional soya. Although legal from a US regulatory point of view, this precluded meaningful labelling. However, consumer and environmental organisations had demanded the 'right to choose' between GM and traditional products. The fact that consumers would not be given such a choice was successfully used by a combination of consumer and environmental NGOs to mobilise the public in most EU member countries. As a result, in many countries retailing chains that were concerned about consumer confidence joined consumer organisations in pushing for clear labelling, and a renewed public opposition led to a heated debate about the appropriate labelling of such products, which industry was unwilling to guarantee.

This event was widely reported in the media and resulted in a change of priorities for regulatory efforts on both national and European levels. The most important effect was that the EU was now pushed to finalise the Novel Food Regulation. Plans for such a regulation had existed since the Release Directive was debated, and the Commission had issued the first proposal as early as 1992.76 From the very beginning, the Novel Food Regulation was meant to cover the introduction of all new food products - including those products of biotechnology that were in principle regulated by the Directive on Deliberate Release. Since the latter did not specify labelling, however, there were major differences between the approvals already granted for maize and soya and those applicable to future products.

The policies of the member countries, the Commission and the European Parliament differed significantly in the question of labelling (Behrens et al., 1997).77 Commission and Council had consistently held a view more sympathetic to industry's arguments than Parliament, and they had tried to regulate the issue within the economic and scientific frame of safety. However, as in the conflict over BSE, influence began to shift from the Commission to the Parliament in late 1995. The Commission accepted a proposal for the Novel Food Regulation that allowed for compulsory labelling under certain conditions. 78 When marketing approvals for GM soya and maize were pending, the labelling question became more and more pressing;79 and when the Novel Food Regulation was passed in January 1997,80 it took most of the Parliament's suggestions into account. This marks a turning point in that the Parliament's views now exerted the greatest influence. However, with the passing of the new regulation, problems lingered on.81 Due to delayed implementation, by 1999 there were still unlabelled products on the shelves throughout Europe that contained modified soya products, if only trace amounts.

Voluntary labelling had been devised as a means to ensure the public acceptance of biotechnology food products. The reluctance of the food industry to label, and the political 
pressure required in compelling them to do so, resulted in a conflict that created obstacles to market entry. Public opposition had reached such a level in some countries that any comprehensive labelling appeared to be a hazard for the producer. Consequently, industry became very reluctant to issue new GM products in the EU. Lacking consumer acceptance for its food products, agricultural biotechnology was in danger of never becoming established in Europe.

In line with a new emphasis on ethics in all fields, ethical questions also began to play a role with respect to the marketing of GMOs. Critics referred to the old problems of how to deal with consumer risk and protection. The growing uncertainty concerning the merits, dangers or moral ambivalence of biotechnology fostered and innervated new actor constellations, such as organisations claiming to address consumer interests and retailer chains. These actors differed in importance, means of influence and power among the European countries but, particularly after 1996, they commanded considerable trust in the public sphere. Their success was facilitated by the provocative way in which multi-national companies had tried to push their GM products in the European market. They made it easier for critics to style GMO producers as villains. Additionally, references to agriculture stimulated particular national sensitivities. 82

However, it was not only plant biotechnology that generated fierce dispute. As the following short excursus shows, other areas of biological research were able to elicit heated responses; and in this case, the moral dimension was writ large.

\section{Dolly and the International Moral Accord}

When, in late February 1997, the first cloning of a mammal from a somatic cell made the headlines in all Western countries, the reactions to 'Dolly the cloned sheep' as a media sensation were of a different quality to the public anxieties about soya and maize. Controversy in this case was not related to consumer concerns, fears of environmental disaster, or outrage at regulatory misconduct. Instead, this was an event that evoked the 'moral danger' of human cloning. The common feeling was that the transgression of moral boundaries was imminent and had to be prevented. In an interplay between international political actors and the media, within days a consensus developed over the whole industrialised world that human cloning should be prohibited.83 In Europe, the media event triggered a more or less synchronous mobilisation of the various national publics, but the issue was still discussed on a national level. As with the GM soya case, there was still no common 'European' public, even if debates were now emerging in countries in which the public had hitherto been virtually silent on the issue of biotechnology (for instance, in Greece, Italy, Poland and Ireland). 84

As an affirmation of this moral consensus, instant policy responses emanated from the Pope, the American President, the British Government and the European Commission. The case of Dolly gave authorities an opportunity to demonstrate their responsiveness to public moral sentiment by announcing prohibitions in the form of various pieces of legislation on reproductive medicine and patenting. Their swift action was surely designed to renew trust in regulators and prevent a spill-over effect on the image of biological research. However, in the 
public eye, Dolly became linked to other aspects of biotechnology, again transgressing the borders of a purely scientific understanding. Thus, by alluding to the human presumptuousness of interfering with (arguably) natural or sacred orders, biotechnology assumed clearly negative moral connotations, in spite of the international moral accord.

\section{National Responses to Public Opposition}

Fading consumer trust prompted national publics to exert pressure on their governments. Additionally, in 1996 and 1997 some 'latecomer' countries experienced the trigger events of the first experimental releases of GMOs, and these prompted public debates of a hitherto unknown character. Another factor militating in favour of opposition was that in 1997 and 1998 elections transferred political power to centre-left governments in France, the UK and Germany. The new governments increased the attempts begun under their predecessors to rebuild public accountability in matters of food safety. With governmental changes, the arguments of critics became more influential than before, and the balance of power in the EU Council of Ministers also changed.

\section{'Latecomers' catching up}

The first country to witness a broad public mobilisation against biotechnology during phase 4 was the new EU member Austria. While there was no noticeable public or media interest until 1996, the first release of GMOs caused considerable turmoil for the Austrian authorities and the biotechnology industry.85 A 'people's initiative' (an official petition) calling for a moratorium on agricultural applications and patents received high levels of consent and placed the government and administration under considerable political pressure. In early 1997, authorities imposed a ban on the import and agricultural use of Bt-maize, despite the Commissions' market approval, and hence they deliberately violated EU-regulations. Austria upheld the ban while the Commission, mainly for procedural reasons, failed to enforce its regulation.

In other small and new member states, such as Greece and Ireland, without any previous debates on biotechnology, the first GMO releases triggered public opposition in an atmosphere affected by the Dolly story and by controversies on food safety. In Greece the first release took place in spring 1997. This encountered opposition from NGOs which occupied test fields and succeeded in gaining media attention. As in parts of Austria, Greek agriculture is small in scale and there is an increasing market for organic products. In November 1998, Greece followed the Austrian path in banning GM oilseed rape, which had previously been approved EU-wide.

Due to close trade relations with the UK, Ireland was particularly affected by the BSE-crisis. As in Greece, the first releases took place in spring 1997, meeting NGO resistance that manifested itself in the destruction of fields. During the election campaign of 1997, agricultural biotechnology was a contentious topic among the critical Irish public. During a temporary moratorium the Irish government organised (public) consultations over the summer of 1998. Subsequently it announced a moderate policy that undertook to consider consumer protection to be a priority, but would aim to secure economic and employment opportunities, revoking its initial promise to prohibit agricultural biotechnology. 


\section{'Forerunner's' decelerating}

However, changes in public and governmental attitudes towards biotechnology were not confined to small countries. The most astonishing reversal took place in France, where the conservative government discovered the merits of involving the public in decision-making before the election in spring 1997 (which brought a coalition of the Socialist and Green parties to power). The scientific-elitist style of biotechnology policy of the previous phases would have rendered such a step almost absurd. Yet, even though it was the French administration that had filed the request for the EU-wide marketing of the US soya/maize imports, it nevertheless decided to suspend the distribution of GM maize. Under the new government, environmentalist NGOs, agricultural syndicates and the Green Ministry of the Environment took a tough stance against agricultural biotechnology, which in turn had strong vested interests in agriculture, industry and research on its side. In autumn 1997, a 'citizens' conference', designed after the Danish model of consensus conferences, was scheduled for June 1998. Future policies were to be linked with the outcome of this consultation.86 The French government followed the recommendations that were formulated and imposed a twoyear moratorium on marketing authorisations for certain plants.87 Remarkably, after the conference the government's position was similar to that in Ireland subsequent to its consultation process: while consumer protection and environmental safety gained high priorities, biotechnology was still officially viewed as a key technology with huge economic potential that had to be supported.

Unexpectedly, the $U K$, too, experienced a reversal in its earlier policy. Compared to many other countries, the British consumers had never found GM food particularly unacceptable and biotechnology in agriculture had not been a contentious issue for environmental NGOs. The British system of selectively involving potential dissenters in decision-making had worked well in containing conflicts. The BSE-crisis, however, had created a new situation. 88 Before the election, the Conservative Government had faced a severe loss of public trust for various reasons. After its victory, the new Labour government was more reluctant than its predecessor to see biotechnology as a predominantly economic issue. Shortly after the election, Britain experienced an intensification in public debate. 89 The British government even considered a temporary moratorium, but instead promised a series of 'public consultations'.90 In 1999, links with BSE were asserted after allegations were made that experimental data showing negative health effects linked to the consumption of transgenic potatoes by rats had been suppressed. These accusations resulted in a public uproar over regulatory misconduct.

In the early Nineties, Germany had abolished the cautious policy it had adopted during the late eighties, when it had accepted a number of green caveats. Now it moved in the direction of other European countries and assumed a more positive attitude towards biotechnology. The conservative-liberal government had decided to embrace new technologies, even if the public did not particularly approve of them, in order to regain German competitiveness. Since there were other issues at stake, for instance, re-unification and the rise in unemployment, public opposition had been hardly visible when regions had been applying for special funding to set up new biotechnology facilities. However, surveys showed continuing public unease about agricultural biotechnology. When the Social Democrat/Green coalition took over in 1998, 
they acted more cautiously with respect to these hidden public anxieties, although they did not relinquish their industrial modernisation commitments. Agricultural and food biotechnology received less support, while the backing of medical research and the production of drugs and vaccines remained stable.

The Scandinavian countries had always harboured populations very critical of biotechnology.91 The BSE-crisis had surprisingly little impact, but the soya/maize-episode strengthened the bargaining positions of NGOs opposing biotechnology, thus affirming already sceptical attitudes. Food retailers and NGOs together lobbied for extensive labelling and a cautiously gradual introduction of GMOs. In Denmark, opposition groups and lobbyists tried to influence regulation policy, or at least its implementation, and they attempted to prohibit the marketing and selling of products that were not properly labelled. Norway continued to hold the most critical position and tried to maintain its commitment to 'sustainability' and 'societal benefit' criteria in evaluating particular GMOs.

In the Netherlands, the government's obligation to inform the public of both positive and potentially negative effects of the new products had already been a constituent of official policy. This was intended to permit consumers freedom of choice and to provide a basis for public acceptance. Government was, likewise, to guarantee the safety of products and to be receptive to uncertainty and concerns among citizens (van Vugt \& Nap 31 f.). This, in 1996, the Netherlands were very active in informing the public and the media in workshops about market introductions of GM food, and the government promoted participation in EU research programmes for stimulating consumer acceptance of biotechnological products. Differences between consumers, retailers, producers, and NGOs may have been divisive (Smink \& Hamstra 199 ), but negotiations in line with the Dutch regulatory tradition succeeded in reconciling most of the disagreements. As a result, the Dutch government continued to be in a position to demand significant de-regulation, even after the soya conflict.

\section{Exceptions}

Two countries did not follow the general European trend. Although a Scandinavian country, Finland's positive and pragmatic attitude towards biotechnology seemed to have been unaffected by general European developments. As in previous phases, biotechnology was still seen as a means to modernise the country and to gain economic advantages, although there were still only a few small biotechnology companies.

In early summer 1998, a referendum on biotechnology was held in Switzerland to finally resolve a political conflict that had been going on continuously since the late eighties. At that time, the developments described in other European countries were already under way. The outcome was open, but the referendum represented a clear defeat for the critics of biotechnology. The reasons for this development, one that appears to run counter to the new 'critical' European trend, are twofold. Firstly, though the debate about biotechnology was old, because of its traditionally time-consuming public participation procedures the Swiss political system had reacted very slowly to this issue. Hence, the wording of the referendum did not mirror the recent preoccupation with GM food, but emphasised transgenic animals and, therefore, medical research. Secondly, an estimated 200 pharmaceutical companies and specialised research institutes constitued a major asset to the country's economic well-being. 
Aware of the importance of biotechnology in maintaining national competitiveness, Swiss industry, researchers, students and the government formed a broad alliance and engaged in a co-ordinated campaign. One reason for their success was that, in the Swiss debate, they concentrated on medical research and pharmaceutical applications rather than on food or agricultural products, in clear contrast to the rest of Europe. Another factor may have been that Swiss pharmaceutical companies are technological world leaders, and are consequently linked to national pride as well as to economic success.

\section{The European Consumer}

\section{Towards a European Public?}

After imported GM crops had reached most European countries, reactions to biotechnology became pan-European, and debates arose in countries in which the public had hitherto barely been aware of biotechnology. In addition, some NGOs became players on the European level. The increased consumers' anxiety felt in many European countries indicated a certain harmonisation in beliefs, and the European institutions' actions could be interpreted as reflecting them. This raises the question of whether something like a 'European public', in contrast to phases 1,2 and 3 , had emerged. The preceding periods had seen public controversies remaining strictly confined to national contexts. There had been neither a common European debate nor a European public, since the basic prerequisites of a common language, European mass media or opinion leaders, let alone a common identity, had not existed.

Yet, if the new conflict was no longer confined to single countries, debates were not truly 'European'. The above prerequisites still were lacking, and the publics in the respective countries remained more or less isolated. Instead, from 1996 onwards the GM food controversy triggered parallel, but separate, reactions from the European national publics. The media concentrated on national events, and only occasionally covered controversies in other countries.

The pressure on the national governments and, in consequence, on the European regulatory system led to a redistribution of influence. At the EU level, the European Parliament succeeded in styling itself as the representative of a fictitious European public opposed to the European government represented by the Commission. This stance was based on an understanding of public interest in terms of the consumers' right to choose, notwithstanding issues of risk, but clearly taking account of the recent experiences with BSE.

On the other hand, this consumer orientation conflicted with international agreements, made during phase 3 , to liberalise trade. These agreements ruled against non-tariff trade barriers that might prohibit imports. Promoters of free technology flow intended such agreements to make the handling of biotechnology more equal across countries.92 But these legal requirements left little room for political manoeuvre in response to public opinion or even statutory processes of public participation. Everything relied on scientific risk assessment, and social value judgements were explicitly forbidden. Nor could the precautionary principle 
override the requirements of the agreements, rendering the former more or less toothless (Vogel, 1996).

Consequently, the Commission was more inclined to seek expert advice and strengthen the role of scientific committees ${ }^{93}$ in defining risks in accordance with scientifically defensible, 'hard facts'. The role of scientific experts had become statutorily paramount. Rational as this appeared, it was problematic from a public policy point of view since public trust in experts appeared to be declining. Thus, situations such as in Austria could occur, where a people's initiative demanded a ban on GM food, whereas EU regulation - in line with international treaties - enforced importation. Such a divisive juxtaposition of the 'peoples' will' and international trade agreements triggered further public opposition.

\section{Global Issues}

\section{The US: A Different Agenda}

The declining public faith in experts and regulators in Europe again highlighted the differences between the US and the European regulatory approaches. Comparative studies of the development of regulation and market introduction of consumer products had already shown an important division. In general, EU regulation was more paternalistic, involving a reliance on experts who were considered to be pro-actively protecting the citizenry (McKelvey, 1997). This was partly a response to the variety of regulatory styles among the member countries. When, as a reaction to consumer concerns, the frames of the debate on biotechnology in Europe broadened, the debate on protectionism versus the free market intensified and market relations between the US and the EU came in for serious scrutiny.

From the perspective of the US and Canada, EU policy was protectionist and represented an illegitimate attempt to gain economic advantage (McKelvey, 1997, p.135). Considering the virtual absence of public opposition to GM food or releases of GMOs in North America, it was hardly conceivable to the Americans that this represented a substantive political problem in the EU. But for democratic reasons, the EU could not ignore public opposition. As with previous transatlantic quarrels over food issues, this dispute was fed by differences in public attitudes as well as market interests.94

In contrast, rather than GM releases and products, in the US during the mid-Nineties the results and implications of the Human Genome Project were causing the furore. In particular, the public was anxious about the possible use of knowledge on individual risk factors for diseases or behavioural traits by health and life insurance companies, as well as in the labour market. In European countries, these themes attracted little attention, presumably because, in European social security systems, individual risk factors play lesser roles in terms of eligibility and premiums.

\section{Patents: a Global Asset}

Another contested area was that of intellectual property rights. In 1996, the OECD issued a report in which it described different approaches to patenting (OECD, 1996), building on an 
older report from 1985. Patenting had been a recurrent issue at least since the first patent of an animal was granted in the US in 1988 and in the EU in 1992. Most disputes, however, arose over two issues: firstly, the patenting of genetic sequences triggered controversy since it was not clear whether such sequences were indeed true 'inventions', or whether they were just 'found' in nature. Secondly, sequence data were considered 'raw material' for basic research and future development that should not be withdrawn from the public domain, as a result researchers themselves were involved in a conflict of interests. Some scientists pointed to industry's growing role as a promoter of basic research, and stressed the necessity of securing intellectual property rights as a reward for the companies' spending of research money. Others saw the quick and free flow of scientific data, a prerequisite for basic research, to be in jeopardy. The issue highlighted the differences in understanding between the US and European countries about what an invention is, and about the proper relations between private enterprise and the public domain.95 96

NGO representatives saw this area as the real challenge for the future: might genetic information be privatised? Should companies be allowed to acquire the right to do what they wished with such information once a patent had been granted? And, should groups such as farmers (especially in the Third World) be denied the right to produce seed? In their view, the issue touched on the more general problem of the ever-increasing power of international capital to command the resources of life.

Yet, though NGOs perceived the patenting question to be crucial, this issue did not have the same power as GM food in mobilising the public. This is because it had no immediate impact on the consumer, but instead concerned such elusive themes as equity, international relations and future development. Obviously, such issues were less contentious to the public than domestic affairs and, especially, risks to human health and the immediate environment. Furthermore, the intricacies of the patenting debates were far too involved and complex to be presented as the catchy and simplistic stories required for effective public communication. Nevertheless, patenting remained an issue of dispute for some time in the European Parliament and elsewhere.97 It was eventually resolved in 1998, when Parliament accepted a Commission proposal for a Patent Directive largely following industry interests, after long and complicated political negotiations.

In the reservations on patenting, one can trace the impact of the Dolly story. In the aftermath of this media event, various publics, governments and EU-institutions unanimously shared the opinion that human cloning had to be rejected. Dolly rendered it easy to insert a prohibition into the directive, because while the economic significance of human cloning remains doubtful, the matter touched upon a common moral code. The prohibition of patenting human cloning techniques may be regarded as a high gain in terms of political publicity at low cost, since no substantial (industry) interests had to be violated. In contrast, the debate about GM food and the accompanying regulatory turmoil had little influence on the final debate about the Patenting Directive. This was an indication that the general debate on biotechnology itself had split up into diverse conflicts on deliberate release and food products, on cloning and xenotransplantation, on intellectual property rights, and on the 'ownership' of genes, etc.

\section{Life Sciences}


Intellectual property rights as a basis for the control of genetic material and biotechnological methods had profound implications in two key, previously almost unrelated, areas. The mergers of gigantic companies engaged in the production of pharmaceuticals as well as seeds indicated that the combination of these two areas would indeed secure future gains.98 It became clear that biotechnology had, finally, achieved a significant status. Even if there were problems concerning the public acceptance of GM food products in Europe, the progress of biotechnology now seemed inexorable. The industry's promises, that had won them backing on the stock market, finally began to come to fruition in the form of multinational companies whose activities centered on biotechnology.

Ironically, this marked the end of the use of the term 'biotechnology' itself. Such companies now stopped using the word since it had acquired negative connotations. Instead, they defined the area as 'life sciences', a term with suggestions of more welcome medical applications. This new term had been in use for decades to identify the fields of biomolecular and basic medical research, and was employed in the titles of university faculties and scientific journals. It gained a new meaning when industry adopted it to identify companies that apply particular methods of biotechnology, irrespective of the field, to developing new products, and acquired patents on genetic sequences as a basic resource. The 'life industry' shed from unrelated activities within chemistry, etc., indicating that the use of life (Bud, 1993) was indeed their core field of interest.

\section{Summary}

In phase 4, when the first GM crop plants entered the Common Market, concerns about agricultural biotechnology brought about a shift in public debate and policy both in the member countries and at the EU level. The dominating economic frames of previous phases became weaker as public opposition increased, while the Directives failed in their objective of harmonising the member countries' interpretations of product assessment. The signals from consumer groups, retailers, and NGOs were now explicit: they did not want their food to be produced using biotechnology, and they demanded the right to choose, regardless of safety issues. As a consequence, labelling became paramount. The debate coincided with the advent of new and contentious cloning techniques, again establishing a link to reproduction that had already largely vanished. It seemed as if the debate on biotechnology had fallen back to a starting point, notwithstanding its preliminary fading in phase 3 , although debates diversified and became centred around certain application and problem fields

In response to public opposition, and supported by government shifts in important member countries, the EU policy turned towards a more cautious implementation of GM food products. This, however, caused problems with international and transatlantic trade agreements. Even more far reaching policy issues centred around intellectual property rights, especially the patenting of genetic sequences. While companies merged to form conglomerates engaged in both medical and agro- biotechnology, the term 'biotechnology' began to disappear from corporate language, being replaced by the even more inclusive, but less contentious, 'life sciences'. 


\section{Résumé}

\section{Regulation to Make Biotechnology Happen}

From the very beginning, most national governments, as well as the EU Commission, tried to 'make biotechnology happen'. This motive became dominant in the Eighties, when the economic point of view was advanced, and it has remained paramount ever since. Despite various obstacles, governments adopted a double strategy. On the one hand, they fostered industrial and scientific research to the degree that they accepted responsibility even for the establishment of commercial firms. They succeeded to differing degrees, depending on the national industries' capabilities for engaging in the new technology, and on the willingness of the domestic publics to accept its products.

They also tried to reassure a critical public - by implementing credible regulation - that risks could be managed. The major questions were: who should be in the position to regulate, and what would such a credible regulation involve? Was self-regulation by the scientific community sufficient, or were there issues that could not be dealt with in such a system? A major problem was to decide what biotechnology could be compared with: is it something entirely new or merely an extension of older techniques? Is it like nuclear power or like bread baking? If a solution found was generally held to be trustworthy, debates often calmed down.

Over time, however, this strategy became less effective, reflecting a general loss of trust in government and in scientific institutions and experts. Attempts to solve the regulatory problems within an expert system, as in phase 1, failed later on, since governments had to react to the social changes of the Eighties. While some still tried to contain the debate within a strictly scientific frame, others integrated critical actors in the decision making process as a sign of openness towards the public. It was hoped that this would prevent the spread of the critiques advanced by NGOs without jeopardising the economic potential of biotechnology. But, another reason why safety regulation failed to close the debates was that it could not cover any more the issues at stake.

\section{The Failure of Risk Assessment}

When it was introduced, the supporters within science, policy and industry expected that it was only a question of time until biotechnology was generally accepted by the public. From their points nof view, possible risk, to be assessed in a scientifically rational way, was the only obstacle to popular acceptance. Consequently, innovators intended to restrict the debate to classical risk assessment, but they eventually failed in doing so because of the lack of universally shared criteria. Studies on risk perception indicate that lay people perceive risks differently from scientific experts (Slovic, 1987: see also Douglas \& Wildavsky, 1983, pp.4966; Jungermann \& Slovic, 1993). The latter tend to keep the problem solely within what they perceive to be a purely technical frame, while the former implicitly emphasise behavioural, cultural, social and economic aspects. This was hard for scientists to comprehend. Following, as they were, a rationality that demanded keeping value consideration to one side, they could not understand why risk debates were transgressing the issue of (physical) hazards and put up questions of equity and accountability. Such value choices, however, are the most decisive 
factor shaping public perceptions (BEP, 1997). When experts kept affirming that risks were negligible or manageable and need not hinder progress, they were consequently reproached by the public for downplaying the potential risks. As scientists were in a position to moral judgements, and were stakeholders themselves, they could be accused of being partisan and hiding conflict of interest. This undermined their credibility. 99

As a consequence, the question of whether there were significant risks - notwithstanding the apparent lack of accidents - could never be sufficiently answered. This led to the adoption of the cautious principle of case-by-case and step-by-step assessment in the EU-regulation, which were themselves predicated on the precautionary principle. Uncertainty was the reason why regulation was put in place until 'more experience' was acquired - again, this was subject to different interpretations and hence to regulatory uncertainty, leading to delays. Thus, the dispute over risks slowed down the pace of innovation; it even temporarily stopped it or forced it on sidetracks. Yet, the low speed of implementation may have contributed to the safety of the new technology. We may speculate that, had it not been for scientific, regulatory and public scrutiny, we might indeed have experienced accidents.

\section{Biotechnology as a Sounding Board}

As biotechnology left the laboratories and entered society, its image varied considerably depending on what was considered technically feasible and what was deemed desirable. The focus on applications meant that the term 'biotechnology' became a symbol according to promoting or preventing interests. 100 Supporters and critics competed in establishing the 'meaning' and definition of biotechnology, and this resulted in terminological shifts. Applications themselves shaped the varying definitions of demands and risks with respect to fields, interests and world-views. Projections of future demand built on promises, sometimes vague, of new products to come, which would outperform conventional ones or be entirely novel. According to the particular application, claims of risk were extended beyond human health to a wide variety of issues, from environmental protection to socio-economic factors. Opposition was often (strategically) based on the logical impossibility of proving the absence of any negative long-term outcomes.

Regulators had to find a way through the complexity of arguments, while uncertainty about risks prevailed. Uncertainty controversies featured two types of argumentation. On the one hand, physical hazards (health and the environment) were emphasised, and on the other, societal and moral issues came to the fore, involving consumer rights, trust in experts and regulation, and the role of agriculture in post-industrial economies.101 Both types of argument influenced attitudes but, in general, societal and moral arguments turned out to have the greatest impact on consumer behaviour (BEP, 1997; Durant et al., 1998). However, risk issues were the more commonly addressed, since they were (seemingly) independent of individual world-views. Any biotechnology regulation 102 permitted authorities to address physical risks only, so they had to cover other concerns under risk arguments.103 In contrast, Parliaments were able to take up societal and moral issues as well, even if they had little influence on actual decision-making.104 
A similar division could be observed at the EU level. While the Commission statutorily focused on risk only, such arguments helped the previously less important European Parliament to realise its potential as the representative of a common but invisible European public. It acquired, temporarily, a role as consumers' advocate.105 So, during the BSE crisis, the Parliament took up risk issues, but eventually went beyond these and addressed the societal/moral arguments that the Commission could not adequately deal with. Later, in the same vein, the labelling of GM products became not only an issue of paternalistic'risk prevention', but also of 'consumer democracy' in the Parliament and elsewhere.106

\section{National Diversity and European Integration}

In Europe, the new technology encountered a different 'climate' in each country. Its reception varied according to each state's academic tradition, its industry research base, and the players that had tended to influence government policy. Obstacles to broad and smooth implementation also often emerged from cultures critical of technology, the same countries that, during the Seventies and Eighties, had seen social and environmental conflicts over nuclear power, environmental issues, disarmament, women's rights or third world support, etc. Later, such conflicts found their expression in the presence of Green parties in several Parliaments. Another factor involved the existence of religious traditions that objected to the 'manipulation of Creation'. This diversity in response to biotechnology made it more likely that national debates would be confined to national boundaries. Thus, in general, early debates throughout Europe focused upon national events. Only when the first transgenic crop plant came on the market was simultanous media attention provoked in almost all European countries. Similarly, the BSE crisis had a huge trans-national impact, and later the advent of Dolly the sheep became an international media event. However, even in these cases, the actual debates remained mostly national.

There was no general rule as to how governments dealt with biotechnology conflicts. Their response depended, among others factors, on the way political problems were generally handled and whether there was a generally adversarial or consensual style of resolving them. Government reaction was also affected by whether or not other conflicts allowed biotechnology to appear on the agenda, and on the particular understanding of what biotechnology 'really' means. If regulators understood biotechnology to be similar to other technologies, regulation took into account the varied forms of application, and a strong emphasis was placed upon scientific expertise. In contrast, if biotechnology were seen as something new, entailing unknown risks that had to be broadly debated, regulators tended to enact universal laws affecting the technology itself. Some governments tried to keep issues within the realm of scientific expertise; others emphasised public accountability. All this contributed to the striking levels of national diversity.

When, in the late Eighties, biotechnology appeared as an economically promising area of technological development, the US had already taken the lead, and Europe was lagging behind. The EU decided to create a common market for biotechnological products in Europe in order to exploit the industrial opportunities. A pre-condition for this was the implementation of unified regulation, involving a compromise that recognised national differences in regulatory culture and public opinion. After all, Germany appeared as a 
menacing example of what could happen if public opinion was allowed to play havoc. The EU guidelines on contained use and deliberate release met German demands in that the biotechnology itself was regulated, and a kind of precautionary approach was applied, not least in response to public demands.107

The Directives were intended to serve multiple purposes beyond that of ensuring harmonisation by defining risk assessment requirements. Following international trade agreements, the Directives had to be compatible with US regulations, though the US believed EU regulations to fall short of this.108 Additionally, the Directives turned out to be the master-copy for countries outside the EU that lacked regulation, but which had close trade relations with Europe, and eventually became EU members. But these aims were set too high. As with any standard resulting from a compromise, the Directives suffered from ambiguities. In particular, the wording of the Release Directive 90/220 left room for interpretation, in the clear expectation that a common European understanding would develop over time. However, despite intensive negotiations over the years, binding rules on crucial issues such as risk assessment criteria for products could not be achieved. Divergence and convergence did not produce an equilibrium.109

Although industry and large NGOs had become European actors, national idiosyncrasies were even more influential when biotechnology entered the agricultural sphere. Since the US demanded free access to the European market for American GM crops, a veritable trade war was looming. Attempts to 'verticalise' the regulation via Directives on Novel Food, Pesticides, Feed, etc. turned out to threaten various other, previously less contentious areas, rather than to solve the problem. National governments, as well as the European Commission, realised that after ten years of harmonisation attempts, disharmony among EU member states over biotechnology policy had not been eliminated and a comprehensive regulation would need to be very complicated. Finally, the century ended with a

\section{Conclusion: No End Of Conflicts}

After a quarter of a century, the future of biotechnology is open. Fields like basic research and development, the production of pharmaceuticals, food additives and enzymes, forensics, diagnostics, etc. have become unthinkable without biotechnological methods. Yet, in other fields, like predictive medicine, gene therapy or environmental remediation, practical implementation has barely begun. Certain areas lag behind for various reasons: seeds commercialised so far have been an agricultural success in the US, but remain contested in Europe. Conversely, genetic testing for disease preconditions 110 may entail problems with insurance coverage, and are more debated in the US than in Europe due to different health care systems. It has become clear that biotechnology, like other modern technologies, is embedded in society - or, rather, in the societies of various countries - and is subject to their differences. Innovation will continue to accelerate, but one may not take it for granted that a product will be welcomed just because it is new or advantageous for the producer. Public concern brought forward (or triggered) by NGOs and attitudes towards the public accountability of regulators and industry will contribute significantly to the success of new products. 
Diversity, as it exists on the European level, is also apparent on the global scale. Multinational companies merge and increase their market power in already monopolised fields, such as seeds and pharmaceuticals, and international agreements will enforce homogenous assessments on a seemingly scientific base. Nevertheless, differences in culture and interests over time and among countries and continents will remain. From a global perspective, the strategy of actors engaged in the promotion or rejection of technology will change, but they will always be influential political factors.

Ten years from now, we may be able to write the history of the debate on biotechnology. However, at present the controversy is still ongoing, and there are few indications that it will soon come to an end. Whether the rapid cultural and technological changes of our times are too difficult to cope with, or if the pertinent technology is too complex to understand, it has become obvious that the current regulatory scheme in Europe does not fulfill what Sheila Jasanoff $(1995$, p.311) postulated to be the essence of a functioning regulation: ,... it is a kind of social contract that specifies the terms under which state and society agree to accept the costs, risks and benefits of a given technological enterprise." To set up such a contract is no less of a challenge today than it was 25 years ago. 


\section{References}

R.Baggott, 'The BSE Crisis. Public Health and the 'Risk Society', in P.Gray and P.t'Hart (eds.), Public Policy Disasters in Western Europe (Routledge: London and New York, 1998), 61-78.

B.Balmer and M.Sharp, 'The Battle for Biotechnology: Scientific and Technological Paradigms and the Management of Biotechnology', Research Policy, 22 (1993), 463-478.

N.Bandelow, 'Ausweitung politischer Strategien im Mehrebenensystem, Schutz vor Risiken der Gentechnologie als Aushandelsmaterie zwischen Bundsländern, Bund und EU', in R.Martinsen (ed.), Politik und Biotechnologie. Die Zumutung der Zukunft, (Nomos, BadenBaden, 1997), 153-168.

M.Bauer, J.Durant and G.Gaskell, 'Biology in the public sphere: a comparative review', in J.Durant, M.Bauer and G.Gaskell (eds.), Biotechnology in the Public Sphere (Science Museum: London, 1998), 217-227

U.Beck, Risikogesellschaft. Auf dem Weg in eine andere Moderne (Campus, Frankfurt, 1986). M.Behrens, S.Meyer-Stumborg and G.Simonis, Genfood. Einführung und Verbreitung, Konflikte und Gestaltungsmöglichkeiten (Sigma, Berlin, 1997).

E.Bongert, 'Towards a 'European Bio-Society'? Zur Europäisierung der neuen Biotechnologie', in R. Martinsen (ed.), Politik und Biotechnologie. Die Zumutung der Zukunft (Nomos, Baden-Baden, 1997), 117-134.

R.Bud, The Uses of Life. A History of Biotechnology (Cambridge University Press: Cambridge, 1993).

M.Cantley, 'The Regulation of Modern Biotechnology: A Historical and European Perspective', in D.Brauer (ed.), Biotechnology, vol. 12 (VCH: New York, 1995), 505-681.

Deutscher Bundestag, Zum gentechnologisch hergestellten Rinderwachstumshormon. Enquete-Kommission „Gestaltung der technischen Entwicklung; Technikfolgen-Abschätzung und -Bewertung" des 11. Deutschen Bundestages, BT-Drucksache 11/4607, Bonn, 1989.

U.Dolata, 'Nachholende Modernisierung und internationales Innovationsmanagement. Strategien der deutschen Chemie- und Pharmakonzerne', in T.v.Schell and H.Mohr (eds.), Biotechnologie - Gentechnik. Eine Chance für neue Industrien (Springer: Berlin, 1995), pp. 456-480.

G.Dosi, Sources, 'Procedures, and Microeconomic Effects of Innovation', Journal of Economic Literature, vol. XXVI (1988), 1120-1171

M.Douglas and A.Wildavsky, Risk and Culture. An Essay on the Selectiuon of Technological and Environmental Danger (Univ. California Press: Berkeley, 1982).

J.Durant, M.Bauer and G.Gaskell (eds.), Biotechnology in the Public Sphere (Science Museum: London, 1998).

J.Ellul, The Technological Society (Alfred A. Knopf: New York, 1964).

European Council (1990), Directive 90/219/EEC of 23 April 1990 on the Contained Use of GM Micro-organisms; and Directive 90/220/EEC of 23 April 1990 on the Deliberate Release into the Environment of GM Organisms. Off. J. Eur. Commun. No. L117/1-27, Brussels.

European Council (1994), Directive 94/15/EC of 15 April 1994 for the First Adaptation of the Directive 90/220/EWG on the Deliberate Release of GM Organisms Into the Environment to Technical Progress. Abl./L 103/20, Brussels.

L.Frewer, 'Consumer Aspects of Public Understanding and Acceptance of Transgenic Animals', in Transgenic Animals and Food Production. Kung. Skogs- och Lantbruksakademiens Tidskrift 20 (1997), 139-144. 
J.C.Galloux, H. Prat Gaumont and E.Stevers, 'Europe', in J.Durant, M.Bauer and G.Gaskell (eds.), Biotechnology in the Public Sphere (Science Museum: London, 1998), 177-185.

G.Gaskell, M.Bauer and J.Durant, 'The representation of biotechnology: policy, media and public perception', in J.Durant, M.Bauer and G.Gaskell (eds.), Biotechnology in the Public Sphere (London: Science Museum, 1998), 3-12.

B.Gill, J.Bizer and G.Roller, Riskante Forschung. Zum Umgang mit Ungewißheit am Beispiel der Genforschung in Deutschland. Eine sozial- und rechtswissenschaftlche Untersuchung (Berlin: edition sigma, 1998).

B.Gill, Gentechnik ohne Politik. Wie die Brisanz der Synthethischen Biologie von wissenschaftlichen Institutionen, Ethik- und anderen Kommissionen systematisch verdrängt wird (New York, Frankfurt/Main, Campus, 1991).

H.Gottweis, 'Governing Molecules. The Politics of Genetic Engineering in Britain, France, Germany, and in the European Union', Habilitation paper, Faculty of Humanities, University of Salzburg (1995).

K.Grosch, P.Hampe and J.Schmidt (eds.), Herstellung der Natur? Stellungnahmen zum Bericht der Bundestagsenquete-Kommission 'Chancen und Risiken der Gentechnik' (Frankfurt/Main, Campus, 1990).

P.Gundelach, 'Research on Social Movements in Denmark', in D.Rucht (ed.), Research on Social Movements. The State of the Art in Western Europe and the USA (Frankfurt/Main, Campus,1991), pp. 262-294.

P.A.Hall, 'Policy Paradigms, Social Learning and the State. The Case of Economic Policymaking in Britain', Comparative Politics (April 1993), 275-296.

A.Hill and M.Michael, 'Engineering Acceptance: Representations of 'The Public' in Debates on Biotechnology', in P.Wheale, R.v.Schomberg and P.Glasner, The Social Management of Genetic Engineering (Aldershot, Ashgate, 1998), pp. 201-218.

T.J.Hoban, 'Consumer Acceptance of Biotechnology: An International Perspective', Nature Biotechnology vol. 15 (1997), 232-234

INRA, 'Biotechnology and Genetic Engineering. What Europeans think about it in 1993', Survey conducted in the context of Eurobarometer 39.1 (1993).

S.Jasanoff, 'Product, Process or Programme: Three Cultures and the Regulation of Biotechnology', in M.Bauer (ed.), Resistance to New Technology. Nuclear power, information technology and biotechnology (Cambridge University Press, 1995) 311-331.

R.Jülich, Öffentlichkeitsbeteiligung im Geltungsbereich der EG-Richtlinien 90/219 und 90/220 im internationalen Vergleich. Die Ausgestaltung von Informations- und Partizipationsrechten in den EU-Mitgliedstaaten, der Schweiz und Norwegen.Öko-Institut, Freiburg, Darmstadt, Berlin, (1998).

H.Jungermann and P.Slovic, 'Characteristics of Individual Risk Perception', in Rück Bayerische (ed.), Risk is a construct (Munich: Knesebeck, 1993), 85-101.

T.Kliment, O.Renn, J.Hampel, 'Die Wahrnehmung von Chancen und Risiken der Gentechnik aus der Sicht der Öffentlichkeit', in Th.v.Schell and H.Mohr (eds.), BiotechnologieGentechnik. Eine Chance für neue Industrien, (Berlin/Heidelberg: Springer, 1994), 558-583.

S.Krimsky, Biotechnics and Society. The Rise of Industrial Genetics (New York: Praeger, 1991).

W.Krohn and G.Krücken, 'Risiko als Konstruktion und Wirklichkeit. Eine Einführung in die sozialwissenschaftliche Risikoforschung', in W.Krohn and G.Krücken (eds.), Riskante 
Technologien: Reflexion und Regulation. Eine Einführung in die sozialwissenschaftliche Risikoforschung (Frankfurt/Main suhrkamp, 1993), 9-44.

L.Levidow, S.Carr, R.v.Schomberg and D.Wield, 'Regulating Agricultural Biotechnology in Europe: Harmonisation Difficulties, Opportunities, Dilemmas', Science \& Public Policy 23 (1996), 135-137

D.Macer, 'Bioethics for the people by the people' (Christchurch, New Zealand/Tsukuba, Japan: Eubios Ethics Institut, 1994).

D.Majone, Evidence, Argument and Persuasion in the Policy Process (New Haven/Conn Yale University Press, 1989).

M.McKelvey, 'Moving to Commercialisation: Invited Response', Transgenic Animals and Food Production Kung. Skogs- och Lantbruksakademiens Tidskrift 20 (1997), 133-138.

R.R.Nelson and S.Winter, An evolutionary Theory of Economic Change (Cambridge/Mass: Harvard University Press, 1982).

T.H.Nielsen, Bioteknologi og biopolitik, 1976-1999, Manuscript, Oslo (1999).

R.Oakey, W.Faulkner, S.Cooper and V.Walsh, New Firms in the Biotechnology industry (London: Pinter, 1990).

OECD, 'Recombinant DNA Safety Considerations', OECD, Paris (1986).

OECD, 'Biotechnology and the Changing Role of Government', OECD, Paris (1988).

OECD, 'Biotechnology: Economic and Wider Impacts', OECD, Paris (1989).

OECD, ‘Safety Considerations for Biotechnology', OECD, Paris (1992).

OECD, 'Biotechnology, Agriculture and Food', OECD, Paris (1993a).

OECD, 'Traditional Crop Breeding Practices: An Historical Review to serve as a Baseline for Assessing the Role of Modern Biotechnology', OECD, Paris (1993b).

OECD 'Intellectual Property. Technology Transfer and Genetic Ressources', An OECD Survey of Current Practices and Policies. OECD, Paris (1996).

OTA (US Congress, Office of Technology Assessment), New Developments in Biotechnology. 4: US Investment in Biotechnology, OTA-BA-360, US Government Printing Office, Washington D.C, (1984).

Pence (1998)

J.G.Perpich, Biotechnology in Society (Oxford: Pergamon, 1986).

C.Pline, 'Popularizing Biotechnology: The Influence of Issue Definition', Sci. Tech. \& Hum. Values 164 (1991), 474

D.Rucht, 'The Study of Social Movements in Western Germany: Between Activism and Social Science', in D.Rucht (ed.), Research on Social Movements. The State of the Art in Western Europe and the USA (Frankfurt/Main, Campus, 1991), 175-202.

D.Rucht, 'Impact of anti-nuclear power movements', in M.Bauer (ed.), Resistance to new technology. Nuclear power, information technology and biotechnology (Cambridge University Press, 1995), 277-291.

W.Rüdig, J. Mitchell, J.Chapman, Ph.D.Lowe, Social Movements and Social Sciences in Britain. pp. 121-148 in: Rucht D. (ed.), Research on Social Movements. The State of the Art in Western Europe and the USA. Campus, Frankfurt/Main, 1991).

A.Sasson, Biotechnologies - Challenges and Promises (Paris, Unesco, 1984).

F.Seifert and H.Torgersen, 'How to Keep Out What We Don't Want. An Assessment of 'Sozialverträglichkeit' under the Austrian Genetic Engineering Act', Public Understanding of Science 6 (1997), 301-327 
M.Sharp, 'The Management and Coordination of Biotechnology in the UK 1980-1988', Phil. Trans. R. Soc. London 324 (1989), 509-523

M.Sharp, 'The New Biotechnology - European Governments in Search of a Strategy', Industrial Adjustment and Policy IV Series, Sussex European Papers no. 15 (1985).

P.Slovic, 'Perceptions of risk', Science 236 (1987), 280-285

S.Slowikowski and D.G.Jarratt, The Impact of Culture on the Adoption of High Technology Products (1997).

G.C.J.Smink and A.M.Hamstra, Informing Consumers About Foodstuffs Made With Genetic Engineering (Leiden, SWOKA, 1996).

B.Tappeser, in K.Grosch, P.Hampe and J.Schmidt (eds.), Herstellung der Natur? Stellungnahmen zum Bericht der Enquete-Kommission 'Chancen und Risiken der Gentechnologie' (Frankfurt/New York, Campus, 1990).

H.Thielemann, 'Kommunikation im Konflikt um die gentechnische Insulinherstellung bei der Hoechst AG', in O.Renn and J.Hampel (eds.), Kommunikation und Konflikt. Fallbeispiele aus der Chemie (Würzburg: Königshausen \& Neumann, 1998), 153-181.

G.Tichy, 'Sozialverträglichkeit - ein neuer Standard zur Technikbewertung?' Österreichische Zeitschrift für Soziologie 194 (1995), 50-61.

P.van Praag, 'The Netherlands: Action and Protest in a Depillarized Society', in D.Rucht (ed.), Research on Social Movements. The State of the Art in Western Europe and the USA (Frankfurt/Main: Campus, 1991), 295-320.

F.van Vugt and A.M.P.Nap, 'Regulatory and Policy Issues as Viewed Within a Cultural Framework: A European Perspective', Transgenic Animals and Food Production, Kung. Skogs- och Lantbruksakademiens Tidskrift 20 (1997), 31-36.

D.Vogel, Trading up. Consumer and environmental regulation in a global economy (Cambridge/London: Harvard University Press, 1996).

R.von Schomberg, 'An Appraisal of the Working in Practice of the Directive 90/220/EEC on the Deliberate Release of GM Organisms', STOA, European Parliament, Luxembourg (1998).

A.Wyndham and G.Evans, 'National Biosafety Legislation and Trade in Agricultural Commodities', BINAS News vol. 4, 2 \& 3, 2-6.

\footnotetext{
1 Supported by the Österreichischer Fonds zur Förderung der wissenschaftlichen Forschung (project no. P11849) and the Institute of Technology Assessment, Austrian Academy of Sciences.

2 According to Rammert, technology comprises 'the inventory of instruments and installations, as well as the repertoire of skills and knowledge, to achieve desired conditions, and to avoid unwanted conditions, in handling the physical, biological and symbolic world.' (Rammert, 1993, p.10, own translation)

3 Apart from the Showa-Denko case of tryptophane contamination, which was mainly due to a failure of the purification procedure.

4 One could argue that (statutory) regulation is always put in place in order to make possible what it regulates (Majone, 1989).
} 
5The European Community (EC) changed its name in 1992 to the European Union after the Maastricht treaty. For the sake of simplicity and consistency, we will refer to both the EC and the EU as the 'EU', irrespective of the actual denomination used at the time referred to.

6 See for example the extensive reviews published earlier by Bud (1993) or Cantley (1995).

${ }^{7}$ If no reference is given for a particular claim made in this chapter, then the claim is based on results fom the above-mentioned research project. Detailed data may be found in Durant et al., 1998.

8 If we define biotechnology in a literal sense, as an activity putting living organisms to work for man, everything from agriculture to fermentation would be included. However, the term is mostly referred to with respect to activities that exceed well-known techniques like baking or brewing etc., more in the sense of what has frequently been called modern biotechnology. We may link its onset to the beginning of broader debates arising over recombinant DNA techniques or genetic engineering. Frequently, the term biotechnology was used as a proxy for the combination of the methods for splitting, sequencing, splicing and constructing genes, including methods for their application in various fields like basic research, industrial production, medicine, agriculture, etc. Genetically modified organisms (GMOs) carry genes modified by these techniques. Consequently, products of biotechnology are the results of production processes applying such methods. In the following, we will stick to this understanding, because it seems to be a common denominator, and not because it provides a scientifically exact definition. It should, however, be noted that the term 'biotechnology' has not been restricted exclusively to the process of recombining DNA. Its broader definition includes processes such as protoplast fusion and cell and tissue culture. This is why the notion of, for example, cloning can be considered a biotechnological activity. Although rather unrelated from a scientific point of view, this example highlight the links to other fields of modern biological $R \& D$, which gave rise to another set of innovations. Even if cloning as a technique has nothing to do with genetic engineering, it has a lot to do with how the public perceives modern biotechnology, as the case of the famous sheep Dolly clearly shows (see below). In public debates, these innovations were at times difficult to separate due to popular representations (Bauer et al., 1998). Therefore we will also have a look at debates and policy responses in such related fields.

9 See comparative textbooks like Parsons, 1996, pp.2-13

10 Obviously different actors conceptualise the public differently but, interestingly, the same actors do so, too, according to different contexts. Hill and Michael for example described what they identified as the decision maker's concept of 'the ordinary member' of that public, being constructed from the ideas of the citizen and of the consumer, respectively. An idealised layperson is thus 'an admixture of (at least) autonomous, thoughtful citizen and concerned, rational decision-making consumers.' (Hill \& Michael, 1998, p.213) This interpretation is in striking contrast to the notion also frequently encountered among scientific and regulatory elites of the 'uninformed public' being basically disinterested in, and dependent on, a mass media that keeps highlighting certain facts and hiding others.

${ }^{11}$ In the following, NGOs.

${ }^{12}$ Some of the then Warszaw Pact states oriented themselves towards the US policy. 
13In 1978, DG XII proposed a Directive against 'conjectural risks' associated with rDNA work, hence the propoal oriented itself towards the technology. However, various reports from European scientific organisations stressed that risks had been exaggerated and relaxation was necessary and possible. This argumentation, following the evolution of policy opinion in the US, prompted DG XII to withdraw the proposal and to opt for non-regulation in the form of a 'recommendation' only.

14 For example, the US Congress' Office of Technology Assessment issued a series of reports emphasising the prospects for medical research, pharmaceutical production, agriculture, and environmental remediation ( e.g. OTA, 1984).

15 Later, the OECD also assigned to biotechnology the status of a crucial cross-sectional technology, like electricity or microelectronics (OECD, 1988).

16 An annual licence for low risk experiments replaced notification in advance, and scientific committees checked the safety on their own.

17 In 1980, a British report conveyed the message to government that commercialisation of biotechnology was both possible and desirable, however competitiveness relied on better technology transfer, which would require more effective support from both government and industry.

18 In France, the early Eighties appeared retrospectively as the 'golden age' of promotional biotechnology policy-making (Gottweis, 1995, p.225), since the strong government backing led to considerable achievements and a catching-up with leading countries like the UK.

19 However, firms especially in the chemical sector were reluctant to take up this entirely new approach. One reason was that among chemists only a decade before, the 'old' biotechnology which the new techniques were based on, had been deemed outdated as compared to the more 'scientific' field of organic chemistry. (see fn.41)

20 The OECD also issued advice about large-scale industrial production (OECD, 1986), but it took them six more years to come up with recommendations for deliberate releases for research purposes, which indicated the associated problems (OECD, 1992).

21 Consequently, in 1980 a new British risk assessment scheme served to facilitate largescale fermentation.

22 There are many interpretations of the precautionary principle, from the rigorous drivers ${ }^{6}$ advice for overtaking: 'if in doubt, don't'; to the more cautious environmental protection version of: 'if there are serious doubts about the outcome, then the one who is less able to defend himself should be given the benefit of the doubt' (i.e., in this case, the environment).

23 Engineered bacteria (the so-caled ice-minus-strains) would protect strawberry plants from freezing. Opponents made claims of (hypothetical) risks associated with the release. These even included the risk of climatic changes. After extensive review by the NIH, permission was granted to carry out the experiment in 1984. However, NGOs took up the issue and succeeded in placing 'genetic engineering' on the agenda again. Activist Jermey Rifkin brought in a law-suit challenging NIH's competence as the first in a series of litigations that significantly contributed to raising awareness or, as others put it, to exaggerate the risks of biotechnology and to cause widespread fear. Rifkins's ligitation series triggered mostly local opposition against single projects. One of the results was that EPA, the US Environmental 
Protection Agency, took up biotechnology as an issue and the releases of GMOs became regulated under existing law (Krimsky, 1991).

24 'As a public controversy, ice minus was history just as soon as the field was sprayed by the moon-suited scientists. A precedent had been set insofar as the first major barrier to the environmental application of GEMs (=GMOs, add.) was overcome.'(Krimsky, 1991, p.132)

$25 \mathrm{rBST}$ is a bovine hormone for stimulating milk production in cows that is produced in GM bacteria. Its approval for use in dairying triggered debates, legal actions and an Enquiry Commission of the German Parliament in 1989 (Deutscher Bundestag, 1989). After protracted disputes, and contrary to the US government, the EU Commission finally denied its approval for use in milk production, which eventually gave rise to a transatlantic trade conflict.

26 For example, German opponents to biotechnology conceptualised the conflict as one between two different paths of development: 'The one path will increase the industrialisation, the technical control of nature and the re-shaping of nature to allow a better exploitation. It is feared that this functionalisation (...) of life will not be limited to plants and animals. The other, desired path of development is described as a path where technological and nontechnological solutions of problems are developed which guarantee a protecting and sustainable dealing with nature.' (Tappeser. 1990, p.10ff).

27 Later the ban on rBST was interpreted by the US as erecting an unfair trade barrier on the part of the EU.

28 Genetic screening allowed the selecting of embryos according to their characteristics. Parents surely wanted healthy children, but what 'healthy' meant depended on cultural definitions. The birth of ill or handicapped children thus became a result of the voluntary decision of their parents.

29 For example, Beatrix Tappesers (see above) affiliation, the Ökologie-Institut in Freiburg, provided counter-expertise, focused on ecological criteria, and was issued from an institutionalised base. This was intended to match the expertise of molecular biologists and industry in the biotechnology struggles and litigations during the Eighties in Germany.

30 This had serious practical consequences, as differences in regulatory styles were the basis of frequent quarrels within the EU about the focus of risk assessment (Levidow et al., 1996) and the definition of 'sound science' in their assessment of products.

31 There were different possible reasons for this: they could not find enough support among the public or from the media; their arguments were not heard by the opinion-leaders; they found other means to achieve partial successes; or, given the fact that most NGOs relied heavily on individual activists, they simply compromised on personal grounds.

32 'The British state either integrates social movements quite well, either directly, in the policy making process, or through political parties, and gives them some limited influence in exchange for co-operation, or it shuts them out completely, denying them any opportunity to influence policy-making' (Rüdig et al., 1991, p.137).

33 'Through the early 1980s, the strategy of containing regulatory debate within carefully structured expert committees ensured a relatively narrow focus on the physical risks of rDNA research and correspondingly muted attention to the social and political consequences of the new technology' (Jasanoff, 1995, p.322). 
34 Around 1989, government tried to counteract the lack of public acceptance by supporting initiatives for multi-actor workshops and installing an ethics committee on environmental safety. A foundation to support knowledge-based opinion formation about biotechnology by consumer NGOs is still functioning.

35 Its 'inventor', the Danish Board of Technology founded by the Danish government in the Eighties, is a body created to assess technology, stimulate public debate and advise Parliament.

${ }^{36}$ The law prohibited releases of GMOs unless the Minister of the Environment found that there were 'special circumstances' for granting an exemption. Eventually, all applications received were exempted from the ban, even without mention of 'special circumstances'.

37 This was also the case in non-member countries joining the EU at a later point in time, for example in Austria and Finland. Finland saw biotechnology as the means for a 'reindustrialisation" of R\&D in some limited areas. Countries on the other side of the Iron Curtain under Soviet domination, like Poland and Hungary, slowly tried to establish a research base whilst orienting themselves towards the US policies, again in the absence of any significant public debate.

38 The Organisation for Economic Cooperation and Development based in Paris; there are 29 members (1999), including the most important industrialised nations and the EU.

39 This was necessary since, if EC regulation was pending, national laws had to be compatible with what was to come.

40 Especially after an unauthorised deliberate release of GMOs in 1987.

41 The ethical debate, which had always been pronounced in France, centered on questions of human medicine and had little influence on the government's position concerning other applications of biotechnology.

42 Particularly the big chemical companies in Germany (with the exception of Hoechst) were reluctant to engage in biotechnology. This was not because of fundamental disadvantages in competitiveness. Ulrich Dolata (Dolata, 1995, p.463) located the reason for German reluctance in the different cultures of the chemical engineers leading these companies, and their devotion to classic organic chemistry as opposed to that of the biologists with their emphasis on biological processes. Meanwhile, US start-up companies had flourished and had partially been incorporated into big established pharmaceutical concerns (Oakey et al., 1990). This had led to a technology transfer, and often entailed their re-orientation towards biotechnology.

43 This was in line with an OECD report entitled 'Biotechnology and the changing role of Government' (OECD, 1988), emphasising its main role to co-ordinate R\&D in this field and to promote its commercial exploitation.

44 In its report of 1985, Parliament 'summed up the political situation for biotechnology at the European Community level. It showed a broad awareness for the potential of biotechnology, and the need for a coherent strategy, responding to the need for international competitiveness. But with respect to regulation it saw 'special risks with genetic engineering methods' (...), demanding a complete ban on field releases 'until binding Community safety Directives have been drawn up' (...), and with similar restrictive views on gene therapy (...) and animal transgenesis (...).' (Cantley, 1995, p.543). 
45 The 'Sixth Amendment", (79/831/EEC) shaped by DG XI (Environment) after OECD proposals and the American Toxic Substances Control Act.

46 Cantley 1995, p.551, citing from the summary of a meeting between the Commission and member state representatives.

47 The first Directive proposal on workers' safety did not cover GMOs only, but 'biological agents' in general.

48 Directives 87/22/EEC for the Production of Pharmaceuticals by New Technologies, 90/679/EEC on Workers' Protection from 'Risks Related to Biological Agents', or the proposal for a Directive on Intellectual Property Rights in Biotechnology and for a Plant Variety Rights System.

49 On the other hand, the European Parliament demanded more restrictive amendments, put forward by the German rapporteur who favoured an approach oriented at possible risks.

50 Another field of debate was the inclusion of the so-called 'fourth hurdle'. NGOs had demanded that applications of biotechnology should be linked to the demonstration of need, additional to the traditional criteria of purity, safety and efficacy in conventional drug assessment. The Commission strictly opposed such demands since they considered them to be an invitation to raise non-tariff trade barriers. Later, only the Austrian and Norwegian laws took up socio-economic criteria, a move with few practical consequences (see below).

51 90/219/EEC on the Use of Genetically Modified Micro-organisms in Closed Systems, and 90/220/EEC on the Deliberate Release of Genetically Modified Organisms to the Environment, to be implemented in national regulation within October 1991 (which was not the case in all member countries). The Directives were issued by the European Economic Community (after 1993 the European Community) within the European Union, hence it is actually inappropriate to speak about 'EU Directives', although they were mandatory throughout the European Union. Nevertheless we will stick to the term for the sake of simplicity.

52 'According to Technical Progress', an amendment to the Release Directive was issued in 1994 (Directive 94/15/EC), specifying categories of plants intended for deliberate release and clarifying details of the risk assessment.

53 The EU deliberately did not regulate genetic testing, gene therapy or any other possible application, fields where national regulations were implemented in some European countries, but not in all. In particular, there was no reference to ethical considerations other than in relation to risks to health and safety and the environment. Any links to reproduction techniques, cloning and the like were omitted. It even remained questionable how the Release Directive would cover the handling of transgenic animals. Another issue that was not touched upon was the dispute about intellectual property rights. In 1988, a US patent had been granted on the Harvard 'Onco-Mouse', which had raised discussions on the 'patenting of life'. In the aftermath, the issue had also created controversy among scientists. The EU prepared a draft Directive that was heavily debated, and it took another ten years before a Directive on intellectual property rights could finally be passed (see below).

54 For example, the question of how to deal with deliberate releases of GMOs showed up on European countries' agendas when the release of ice-minus bacteria was debated in the US. A 
truly public debate, however, arose only when applications for the release of transgenic plants were made within particular countries.

55 E.g. gene therapy, xenotransplantation and genetic testing.

56 I.e. genetically modified

57 Made for the procreation of cows that could produce an anti-microbial protein from human milk in their own milk.

58 The case of Herman the Bull anticipated some of the debates that were to arise later over GM animals as organ donors (xenotransplantation), although medical risks were not at stake

59 In order to broaden the basis for decision making, a consensus conference was held on transgenic animals.

${ }^{60}$ This step was made possible i.a. because the Green Party was no longer in Parliament after re-unification.

61 A way to reconcile the differences was to assign 'societal benefit' to every release for research purposes, since a gain in knowledge was automatically deemed socially beneficial and capable of promoting sustainable development. This was different for certain product applications, however.

62 United Nations Environmental Program and United Nations Industrial Development Organisation.

63 Occasional and sudden outbursts of distrust, as in Poland in 1997, were mostly triggered by NGO actions from abroad.

${ }^{64}$ The OECD recommendations of 'Good Developmental Practice' (OECD, 1992) for small scale field releases did not succeed in playing a similarly unifying role for the US and the EU positions as the 'Safety Considerations' had done six years before. Attempts to link plant biotechnology closely to traditional breeding as a 'baseline for assessing modern biotechnology' (OECD, 1993b) were officially welcomed by both the EU and the US, but they did not resolve the question of how to practically assess newly introduced genes introducing traits that had not been seen before in crop plants.

65 There were even more far-reaching differences, since it was by no means clear what an acceptable outcome of the risk assessment was, or what exactly should be prevented when GMOs were released.

66 Although disclosure of such files was prohibited, more data could be obtained in Denmark and the Netherlands than, for example, in France or Germany (Jülich, 1998).

67 Mostly from industry, as well as from the governments of Germany, the UK and the Netherlands.

68 For example, a British company sold 'vegetarian' cheese, which was attractive to vegetarians. It was made with genetically engineered chymosin as an alternative to calf rennin. Most modern washing powders contained recombinant enzymes.

69 In 1994, the Directive on Deliberate Release was updated (Directive 94/15/EC).

70 Environmental remediation with the help of biotechnology was not an issue during this period. On the one hand, there seemed to be too little substantial progress, and on the other hand the release of GMOs in order to eliminate pollution appeared, to many Europeans 
engaged in environmental protection, as an idea derived from the most cynical technocratic thinking.

71 Sheila Jasanoff (1995, p.311) described the study of the political regulation of biotechnology as the 'study of the process by which technological advances overcome public resistance and are incorporated into a receptive social context'. This diagnosis, taken from US experiences, appeared to also hold true for Europe until the mid-Nineties.

72 This was acknowledged by an OECD report on 'Biotechnology, Agriculture and Food' in 1993: 'High levels of uncertainty surround the innovation process.' (..) 'Biotechnology innovation involves new forms of co-operation between economic actors situated at different points in the agro-food system.' And: 'Successful innovation demands greater responsiveness to end-users whether they be other firms or the final consumer.' (OECD, 1993a, p.143)

73 World-wide acreage covered with transgenic crops exploded between 1996 to 1998, e.g. for soya, from 0.5 to 17 million hectares (according to the Austrian Press Agency, 3.12.1998)

74 Bovine Spongiform Encephalitis (BSE), a nervous tissue disease transmitted by prions (agents consisting of only protein). Known as Scrapie disease in sheep, mostly British cattle acquired the disease from being fed food additives derived from sheep carcasses, although experts had deemed impossible any transmittance across species borders. There is a very rare and similar condition in humans called Creutzfeld-Jakob disease. When an unusual number of new cases of this disease occurred in Britain, experts again reassured the public that there were no indications of a trans-species transmittance between cattle and man. In 1995, however, the possibility of a link was officially conceded after the leaking of information from a secret report.

75 The biggest problem for the EU Commission had been the collapse of the common beef market. Apparently giving in to British pressure, the Commission lifted the ban on some beef products in 1996 against heavy opposition. 'A simple appraisal of costs and benefits ... confirms that in terms of both socio-economic indicators and political legitimacy the policy adopted had disastrous consequences. ... the costs of the crisis ... far outweigh the short-term benefits of the approach pursued by the UK government and the European Institutions.“ (Baggott, 1998, p. 64)

76 See Lassen et al., in this volume

77 Although the labelled tomato paste had not evoked any public debates, industry and the EU Commission still tried to prevent mandatory labelling, and food additives were excluded from the regulation's scope. On the other hand, the European Parliament's Economic and Social Select Committee had emphasised the consumer's right to choose and demanded that labelling become mandatory.

78 If the new product was recognisably different from existing equivalents; if the product might give rise to ethical concerns or had health implications; or if the actual GMO was present in the product. The labelling debate revealed two fundamentally different approaches. Conventional risk prevention demands, from the authorities, a guarantee that there are no significant risks for human health with any product. The way the product was generated is considered to be of no interest to the consumer, since only the (physical) properties count. Such an understanding allows labelling only when there is a more or less established risk for the public or for certain persons, e.g. those suffering from allergies. This was basically the 
position of the US Federal Drug Administration. On the other hand, the consumer choice approach demands labelling in order to indicate the production process. It provides a choice between products that may be substantially identical but produced differently (i.e., a GM versus a non-modified tomato). This is also in line with a 'negative' labelling in case it can be proven that the product does not contain anything that was genetically modified. Clearly, this approach is much more 'political' and implicitly contradicts the philosophy of international trade agreements (see below). They built on the concept of 'Substantial Equivalence' proposed by the OECD (OECD, 1993a), which was based on the comparison between the modified and unmodified food product. It was acknowledged that uncertainty might play a role, but material differences that should 'matter' had to be established.

79 While the Commission approved the GM soybeans, it rejected further demands by Parliament for a modification of the Novel Food Regulation. In spring 1996 the EU institutions' stances differed to such an extent that a time-consuming mediation procedure set in.

80 Shortly after the approval for maize.

81 Although the regulation was binding from April 1997 in all member states, labelling requirements still were unclear. The Commission had to specify them for soya and maize that had been permitted before the regulation was enacted. Now labelling was also required if modified DNA or protein were present.

82 For example, the French had always had difficulties in accepting an American dictate in matters of agricultural trade, whereas Austria as a full EU member experienced a new regulatory impotence in the face of binding EU regulations, and the Danes re-discovered an unease over agricultural biotechnology that had been buried under a layer of consensusoriented deliberations.

83 See Einsiedel et al., in this volume.

84 See the country reports in Durant et al., 1998.

85 The fact that this release was conducted without official permission triggered an immediate response by NGOs and mass media.

86During the one-year run up, French political actors kept making reference to this planned event, both at the EU level, in international political arenas, and even in summit talks on WTO. The conference itself raised consumers' worries about health risks and scepticism towards the independence of experts advising the government.

87 In autumn 1998 it decided to keep the harvest of modified maize completely off the market.

88 Like the French, also the previous conservative UK government had serious problems during the BSE crisis, which also found its repercussions in the debates over the soya and maize imports pending.

89 During 1998, test fields were destroyed by activists. A court battle took place on contamination by genetically modified plants of an organic farm, among others, and biotechnology companies were 'named and shamed' by government advisors for flouting field trial regulations. The media emphasised consumer concerns about food and choice. The Prince of Wales (amongst others) spoke out against the use of genetically modified foods in favour of 'natural' products from organic farming. 
90 A number of other publicly sensitive issues were addressed by government, including cloning and issues of genetic testing and insurance.

91 Except Finland, see below.

92The WTO agreement on Sanitary and Phytosanitary Measures (SPS) demanded a transparent, solely science-based risk assessment as the only legitimate basis for even the shallowest trade restrictions. However, 'in the context of the WTO, it is unclear what criteria might justify an import restriction under SPS, short of evidence of significant negative impact following release of a GMO.' (Wyndham \& Evans, 1998, p.2ff.)

93 Within DG XXIV, an expert comittee was installed to assess genetically modified products in order to circumvent differences between the evaluations by national governments. The evaluations had proven to be hard to reconcile with each other.

94 For example, the American stance towards artificially processed products that were 'nutritionally enhanced' (e.g. de-cholesteroled or sugarless) usually was more relaxed than European perceptions of an 'adulteration' of such food (Hoban, 1997). On the other hand, the perceived European preoccupation with 'naturalness' as well as the frequently rather lukewarm attitude, compared to the American enthusiasm, to competition and economy of scales appeared irrational on the other side of the Atlantic.

95 It forced some revisions also in traditional plant variety protection, including such issues as the right to propagate an organism e.g. in order to produce seed for own purposes.

96 A different aspect of this issue was the exploitation of genetic data from developing countries' indigenous species or crop varieties by companies from the industrialised world. Issues of intellectual property rights were linked to attempts to secure biological diversity through environmental protection. There were severe disagreements whether trade restrictions would be permissible as the only effective means in order to enforce such a multilateral environmental agreement (Fletcher, 1996). When this was negotiated in the 1992 Rioconference, the issue of sustainable development was emphasised. At the end, 171 parties signed the Convention on Biological Diversity, including the EU, but the US did not agree to the negotiated results. This too had consequences especially in EU countries for the public opinion on the role of US companies and their attempts to commercialise GMOs.

97 The neglect of ethical concerns eventually led to a turning down of the EU Commission's proposal for a Patenting Directive in the European Parliament in 1995, which in turn flagged up the issue for industry (Galloux et al., 1998, p.182).

98 For example, the mergers between Hoechst and Rhone Poulence or Zeneca and Astra in late 1998 resulted in conglomerates that covered exactly these two areas, after they had reduced most other activities they had previously been engaged in.

99 Another problem arose from the time perspective of risk assessment. Classical technical risk assessment is in general retrospective: the risk of future hazards can be determined by applying statistical methods to past experiences. Many opponents of biotechnology held a different concept of risk, which was not oriented at past experiences, but at possible futures (see Krohn \& Krücken, 1993). This change in time perspective had severe consequences for the debates on risk. Because the future cannot be controlled, it is for logical reasons impossible to exclude future hazards, and debates on risk cannot be closed. 
100 For example, when Dolly the sheep appeared, the question whether this was biotechnology or not split even the experts' community.

101 This distinction can also be made for example in the case of BSE: arguments about the hazard of acquiring the Creutzfeld-Jacob-disease are such on physical risk; those on the behaviour of governments, e.g. whether the British government was right in not disclosing ambiguous data, are societal or moral arguments.

102 Except the Norwegian and, partly, the Swedish and Austrian gene laws.

103 A good example are the different reasons why labelling was demanded. On the one hand, labelling should serve to indicate health risks for those consumers that were, for example, allergic to certain ingredients. Onthe other hand, labelling of a product with respect to the technology that was used to produce it was seen as genuine consumers' right. It was perceived as the only means by which a consumer decision on the market could give signals to the producer about the acceptability of his product, rather than legal prohibition.

104 Both the German and the Austrian Enquiry Commissions were considered to have had little impact on the actual biotechnology policy (Grabner \& Torgersen, 1998).

105 This role shed some light on the presently prevailing understanding of democracy in the economy-centred common market: impotent citizens (or, for paternalising state authorities, subjects) should possibly turn into powerful consumers in order to pursue a moral matter. See also the introduction, FN 10.

106 This was also reflected in new alliances between NGOs, consumer organisations and retailers.

107 The EU did not follow the European Biotechnology Council's recommendation to adopt the British model that built much more on scientific evidence.

108 This led to the conflict over 'product versus process'.

109 Among the forces towards convergence were the pressure exerted by international competition and the globalisation of trade and industry, the necessity to orient at guidelines issued by international organisations like the OECD or WTO, and concerns about Europe as an area with high wages and standard of living that demands production of goods with high added value. Among the forces towards divergence were the increasing importance of NGOs acting mostly nationally who could command high public trust, as compared to the eroding trust in expert knowledge after food scandals, developments triggered by the electoral change to governments formed by more leftist or green parties, a strengthening of the importance of national parliaments by governments built on weak majorities, and the acknowledgment of the importance to deal with public concerns by state institutions and companies.

110 Apart from testing in cases of severe inherited diseases, which is generally wellcomed. 